\title{
AERIAL PHOTOGRAPHIC INTERPRETATION OF LINEAMENTS AND FAULTS IN LATE CENOZOIC DEPOSITS IN THE EASTERN PART OF THE BENTON RANGE 1:100,000 QUADRANGLE AND THE GOLDFIELD, LAST CHANCE RANGE, BEATTY, AND DEATH VALLEY JUNCTION 1:100,000 QUADRANGLES, NEVADA AND CALIFORNIA
}

\author{
By \\ Marith C. Reheis and Jay S. Noller
}

Open-File Report 90-41

\begin{abstract}
Lineaments and faults in Quaternary and late Tertiary deposits in the southern part of the Walker Lane are potentially active and form patterns that are anomalous with respect to the typical fault patterns in most of the Great Basin. Little work has been done to identify and characterize these faults, with the exception of those in the Death ValleyFurnace Creek (DVFCFZ) fault system and those in and near the Nevada Test Site. Four maps at a scale of 1:100,000 summarize the existing knowledge about these lineaments and faults based on extensive aerial-photo interpretation, limited field investigations, and published geologic maps.

The lineaments and faults in all four maps can be divided geographically into two groups. The first group includes west- to north-trending lineaments and faults associated with the DVFCFZ and with the Pahrump fault zone in the Death Valley Junction quadrangle. The second group consists of north- to east-northeast-trending lineaments and faults in a broad area that lies east of the DVFCFZ and north of the Pahrump fault zone. Preliminary observations of the orientations and sense of slip of the lineaments and faults suggest that the least principal stress direction is west-east in the area of the first group and northwest-southeast in the area of the second group.
\end{abstract}

The DVFCFZ appears to be part of a regional right-lateral strike-slip system. The DVFCFZ steps right, accompanied by normal faulting in an extensional zone, to the northern part of the Walker Lane at the northern end of Fish Lake Valley (Goldfield quadrangle), and appears to step left, accompanied by faulting and folding in a compressional zone, to the Pahrump fault zone in the area of Ash Meadows (Death Valley Junction quadrangle).

\section{INTRODUCTION}

The site being evaluated as a potential high-level nuclear waste repository at Yucca Mountain, Nevada, lies in a tectonic province in the western Great Basin called the Walker Lane belt (Stewart, 1987). This belt, which includes the Walker Lane as originally defined (Locke and others, 1940), has long been recognized as an area of active faulting containing

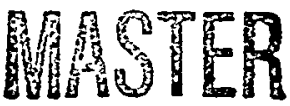

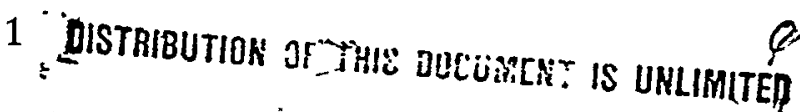


patterns of faults that are anomalous with respect to the typical fault patterns in the central and eastern parts of the Great Basin (Gianella and Callaghan, 1934; Albers, 1967; Stewart, 1987). However, little work has been done to identify and characterize Quaternary faults in the southern part of the Walker Lane, with the exception of faults in the Death ValleyFurnace Creek (DVFC) fault system and faults in and near the Nevada Test Site. This map is part of a study to locate and characterize Quaternary faults within a $100-\mathrm{km}$ radius of Yucca Mountain including the southern part of the Walker Lane. The study is supported in part by the Department of Energy as part of the Yucca Mountain Project under Interagèncy Agreement DE-AI08-78ET44802.

Lineaments and scarps in Quaternary and late Tertiary deposits were identified on stereopairs of black-and-white aerial photographs at scales ranging from 1:24,000 to 1:80,000. The lineaments were transferred to 1:24,000- and 1:62,500-scale topographic maps by hand and by using the stereographic PG-2 plotter. The maps were then photographically reduced and compiled onto 1:100,000-scale base maps.

A numerical scale was devised in order to assign subjective degrees of prominence to the lineaments (see map explanation). Prominent topographic lineaments, such as straight segments of range fronts, were assigned the number 0 . Such lineaments typically separate late Cenozoic deposits from bedrock; in this setting, they suggest Quaternary faulting. Topographic lineaments within bedrock were only mapped where they were associated with known deposits or fault systems of Tertiary age. Lineaments in Quaternary deposits were described on a scale of 1 to 4; increased prominence of the lineament is denoted by a higher number. Our observations indicate that high-numbered lineaments tend to correspond with faults that have experienced either recurrent movement or relatively recent movement. Low-numbered lineaments are less likely to reflect actual faults unless they occur in the vicinity of high-numbered lineaments. Lineaments in Tertiary deposits were described in a similar manner on a scale of 6 to 9 . Finally, the lineaments were compared to those on published and unpublished maps. Lineaments in Quaternary and Tertiary deposits that coincided with mapped faults were assigned the numbers 5 and 10, respectively. In general, mapped faults correspond in prominence to lineaments rated 3 or 4 . The few mapped Quaternary faults that had not been identified during aerial-photo interpretation were added to the map and assigned the number 5. Most of these additions are along the DVFC fault system and are based on new work (G.E. Brogan, K.S. Kellogg, and C.L. Terhune, U.S. Geological Survey, written commun., 1989) that employed 1:12,000-scale low-sun-angle photography to map youthful faulting within this fault system in fine detail.

\section{DISCUSSION OF LINEAMENTS AND FAULTS}

\section{Goldfield and Eastern Part of Benton Range Quadrangles}

There are three major sets of lineaments and faults in the Goldfield and the eastern quarter of the Benton Range 1:100,000-scale quadrangles: (1) northwest- to northnortheast-trending lineaments and faults that are associated with the northern part of the DVFC fault system; (2) north-northeast- to northeast-trending lineaments and faults that lie to the east of the DVFC fault system; and (3) north-trending faults in the northeast corner of the Goldfield quadrangle. An additional, anomalous set of west-northwesttrending lineaments and faults defines the valley between the Silver Peak Range and the Weepah Hills.

Many of the faults that are part of the DVFC fault system display evidence of rightlateral strike-slip motion (G.E. Brogan, K.S. Kellogg, and C.L. Terhune, written commun., 1989). Many north- and north-northeast-trending faults that lie just east of the main fault 


\section{DISCLAIMER}

This report was prepared as an account of work sponsored by an agency of the United States Government. Neither the United States Government nor any agency thereof, nor any of their employees, make any warranty, express or implied, or assumes any legal liability or responsibility for the accuracy, completeness, or usefulness of any information, apparatus, product, or process disclosed, or represents that its use would not infringe privately owned rights. Reference herein to any specific commercial product, process, or service by trade name, trademark, manufacturer, or otherwise does not necessarily constitute or imply its endorsement, recommendation, or favoring by the United States Government or any agency thereof. The views and opinions of authors expressed herein do not necessarily state or reflect those of the United States Government or any agency thereof. 


\section{DISCLAIMER}

Portions of this document may be illegible in electronic image products. Images are produced from the best available original document. 
strands in Fish Lake Valley, however, display only dip-slip motion, such as the cluster of faults on the Indian Creek fan at the northern end of the DVFC fault zone and the faults on the west side of the northern Silver Peak Range. The orientations of both the normal and the strike-slip faults are consistent with an east-west direction of least principal stress and a north-south direction of greatest principal stress. These directions coincide with two directions reported by Zoback and Zoback (1980) in southern Fish Lake Valley and in the Candelaria Hills about $10 \mathrm{~km}$ north of the mapped area. The north-trending faults in northern Fish Lake Valley may function as pull-apart faults in a giant right step between the northern end of the right-lateral DVFC fault zone and the northern part of the rightlateral Walker Lane, which ends about $40 \mathrm{~km}$ to the north.

The north-northeast to northeast-trending set of lineaments mainly lies east of the Silver Peak Range; this set is part of a much larger set that extends south into the Last Chance Range quadrangle and includes both range-bounding lineaments and clusters of lineaments within the valley-fill deposits away from range fronts. Few examples of either * type of lineament have been studied in the field. Of the range-bounding lineaments, only that on the north side of Stonewall Mountain has been previously mapped (Cornwall, 1972). Only one other range-bounding lineament, the west side of Clayton Ridge, has been observed at two localities. The only previously reported lineament clusters within valley-fill deposits were a few in Clayton Valley that were shown as faults in Tertiary deposits (Albers and Stewart, 1972). Some of the clusters within valley-fill deposits have been documented by field observations, including some of the faults in the valley between Clayton Ridge and the Montezuma Range, a cluster of faults at the northeast end of the Palmetto Mountains, and the faults in Stonewall Flat.

The northeast-trending faults could be conjugate shears to the DVFC fault zone. Under the stress field described above, northeast-trending faults would have a large component of left-lateral motion, as well as the observed dip-slip motion. Little field work has been done on these lineaments, but at present there is little evidence that supports leftlateral motion. An alternative possibility is that the northeast-trending faults are a simple expression of dip-slip motion perpendicular to a northwest direction of least principal stress. If this is so, then east of the DVFC fault zone, the direction of least principal stress (northwest-southeast) may be different from that along the fault zone (west-east).

North-trending lineaments in the northeast part of the map area are primarily in Tertiary deposits, but two faults west of Mud Lake displace Quaternary deposits. Where observed, these scarps are degraded and only offset relatively old Pleistocene deposits. These characteristics, combined with the sparse occurrence of these lineaments and faults, indicate that this area is now quiescent. The orientation of the lineaments suggests that they may be a continuation of the north-trending faults characteristic of the Basin and Range province to the north and east of the Walker Lane.

\section{Last Chance Range Quadrangle}

Lineaments and faults in the mapped part of the Last Chance Range quadrangle include: (1) west- to north-trending lineaments and faults that are associated with the DVFC fault system, and (2) northeast-trending lineaments and faults that lie east of the DVFC fault system. In addition, there are two east-northeast-trending lineaments in the Slate Ridge area and a set of north-northwest-trending lineaments south of Stonewall Mountain which show little evidence of Quaternary movement.

The DVFC fault system lies mostly west of the Nevada-California State line, and dominates the map area. Northwest-trending faults associated with this fault system show abundant evidence of right-lateral strike-slip motion (G.E. Brogan, K.S. Kellogg, and C.L. 
Terhune, written commun., 1989). Reverse strike-slip faults mapped at the confluence of Willow Wash and Cucomongo Canyon, in the northwest part of the map, demonstrate that the main west-trending fault there is under compression. Many lineaments in granitic rocks of the Sylvania Mountains are parallel to this section of the fault; those which have been observed in the field represent compressional shear zones in the intrusive rocks. North-trending faults occur in two main areas along the DVFC fault system: in southern Fish Lake Valley and in northern Death Valley near Oriental Wash. The north-trending faults appear to display only dip-slip motion. The orientations of strike-slip, normal, and reverse faults are all consistent with an east-west direction of least principal stress and a north-south direction of greatest principal stress, similar to one direction in southern Fish Lake Valley reported by Zoback and Zoback (1980).

The northeast-trending set of lineaments and faults lies in a zone that begins about 10-15 km east of the DVFC fault system and extends north into the Goldfield quadrangle. In the Last Chance Range quadrangle, this set consists mostly of bounding lineaments on the northwest sides of ranges, including, from southeast to northwest, the Grapevine Mountains, hills west of Bonnie Claire Flat, Gold Mountain, possibly Slate Ridge, and Magruder Mountain. Additional northeast-trending lineaments bound the southeast sides of Magruder Mountain and part of the Palmetto Mountains. Of the northeast-trending lineaments, only some of the ones bounding the Grapevine Range have been documented as Quaternary faults by field observation.

The northeast-trending lineaments in the Last Chance Range 1:100,000 quadrangle could be conjugate shears to the DVFC fault system; however, under the stress field described above, northeast-trending faults should have a strong component of left-lateral motion as well as dip-slip motion. Field observations thus far do not support left-lateral slip on these lineaments. An alternative possibility is that the northeast-trending faults, like those of similar trend to the north in the Goldfield 1:100,000 quadrangle, are a simple expression of dip-slip motion perpendicular to a northwest direction of least principal stress.

\section{Beatty Quadrangle}

There are three major sets of lineaments and faults in the Beatty 1:100,000 quadrangle. A set of northwest- to north-trending faults and lineaments in the southwest corner of the map is associated with the DVFC fault system. A second set of north- to north-northeast-trending faults occupies the north-central part of the map and extends north into the Pahute Mesa 1:100,000 quadrangle. A third set of northeast- to eastnortheast-trending faults lies in the eastern third of the map.

The northwest- to north-trending faults and lineaments of the DVFC fault system include two groups: (1) a group of faults that are presently active, display evidence of right-lateral strike-slip motion (G.E. Brogan, K.S. Kellogg, and C.L. Terhune, written commun., 1989), and lie on the floor of Death Valley; and (2) a group of faults and lineaments that are inactive and bound or lie near the western front of the Funeral Mountains. The northwest orientation of the active strike-slip faults suggests that the least principal stress direction in the area of the DVFC fault system is east-west and the greatest principal stress direction is north-south. The principal fault of the second group is the Keane Wonder fault (Hunt and Mabey, 1966). This fault and associated lineaments appear to have acted previously as a range-bounding fault, perhaps in late Tertiary or early Quaternary time; only a few north-trending lineaments and faults at the southern edge of the Keane Wonder Fault cut Quaternary deposits. 
The north- to north-northeast-trending faults in the north-central part of the map bound the east side of Bare Mountain and cut Yucca Mountain. These faults represent the southern end of a zone of north-trending faults in the Pahute Mesa quadrangle to the north. The faults on the east side of Bare Mountain have thus far been observed to display only dip-slip motion (Reheis, 1988). However, limited evidence suggests that faults cutting Yucca Mountain have experienced both dip-slip and right-lateral strike-slip motion (R.B. Scott, U.S. Geological Survey, written commun., 1989). Fault patterns and slickensides in trenches on one of the Yucca Mountain faults suggest a component of strike-slip motion (J.W. Whitney, U.S. Geological Survey, oral commun., 1989), and earthquakes and movements on faults of similar orientation triggered by underground nuclear explosions on Pahute Mesa had both dip-slip and right-lateral components (Hamilton and others, 1972). Thus, the north- to north-northwest-trending faults in the Beatty quadrangle in part may be strike-slip conjugate shears in a stress field in which the least principal stress is oriented northwest-southeast (Zoback and Zoback, 1980).

The northeast- to east-northeast-trending lineaments and faults in the eastern part of the Beatty quadrangle fall into two groups: one group trends more easterly and is associated with the left-lateral strike-slip Rock Valley fault zone (Ekren, 1968); the second group trends more northerly and lies both north and south of the Rock Valley fault zone. The Rock Valley fault zone proper ends north of the Specter Range, but faults of similar trend but unknown sense of offset extend to the southwest into the Amargosa Desert (Swadley, 1983). The easterly orientation of the left-lateral Rock Valley fault zone is consistent with a northwest direction of least principal stress.

\section{Death Valley Junction Quadrangle}

Lineaments and faults in the Death Valley Junction quadrangle fall into two major sets. The first set consists of northwest- to north-trending lineaments and faults and a few northeast-trending faults in Death Valley and in Furnace Creek Wash that are associated with the DVFC fault system. The second set consists of lineaments and faults of diverse orientation, but generally northwest-trending. This set coincides with the Pahrump fault zone of Fox and Carr (in press). On this map, faults of the Pahrump fault zone extend from the Nopah Range in the south to the Amargosa Desert in the north, and generally follow the California-Nevada State line.

Faults that are associated with the DVFC fault system are divided into two groups. The first group coincides with the Death Valley fault zone. This group displays some of the most youthful faulting in the entire DVFC fault system and is widely distributed along the west front of the Black Mountains (G.E. Brogan, K.S. Kellogg, and C.L. Terhune, written commun., 1989). Unlike faults in the DVFC fault system to the north, these faults and lineaments trend north rather than northwest, and generally display only dip-slip motion. North of Badwater Basin, the jumbled hills that extend from'Natural Bridge north to Mushroom Rock (Artist's Drive fault block of Hunt and Mabey, 1966) are landslides that were probably generated by faulting in upper-plate rocks above an active detachment fault along the western front of the Black Mountains (Hamilton, 1988).

The second group of faults and lineaments associated with the DVFC fault system coincides with the Furnace Creek fault zone. This group trends northwest along Furnace Creek Wash. At the northern end of Furnace Creek Wash, these faults clearly offset Quaternary deposits. The faults appear relatively inactive at the southern end, but there are a few lineaments in Quaternary deposits north and east of Travertine Point. In addition, northwest-trending lineaments and faults at the southern end of Furnace Creek Wash appear to bend into or intersect with northeast-trending lineaments that bound bedrock blocks at the southern end of the Funeral Mountains. 
Little is known about relative motion on the individual faults of the Pahrump fault zone, but the sense of movement on the faults in the area of Stewart Valley is right-lateral (Burchfiel and others, 1983). Some of the lineaments bound ranges, such as the Nopah Range and the hills on both sides of Stewart Valley, but most occur in valley bottoms, especially in the area of the Amargosa Desert and Ash Meadows. The weak topographic expression of many of these valley-floor faults suggests that strike-slip motion may be more important than dip-slip motion along the Pahrump fault zone.

The faults of the Pahrump fault zone terminate abruptly on the north at a zone of east-northeast-trending lineaments and faults. Most of the east-northeast-trending faults lie just to the north of the map boundary (Swadley, 1983), but one is shown here north of Ash Meadows. This zone appears to be an extension of the left-lateral Rock Valley fault zone.

Although detailed mapping is required, the patterns of the lineaments and faults on this map are consistent with the following interpretation, first suggested by Fox and Carr (1989): the Pahrump fault zone is a right-lateral strike-slip system that is offset relative to the Furnace Creek fault zone by the left-lateral Rock Valley fault zone. The least principal stress direction is most likely east-west. Two lines of evidence support this interpretation. First, the Furnace Creek and Pahrump fault zones terminate against lineaments and faults that appear to lie on an extension of the Rock Valley fault zone. Second, recent field mapping by W C Swadley (U.S. Geological Survey, written commun., 1989) and aerialphoto interpretation indicate that late Cenozoic sediments are severely folded and faulted in the area of Ash Meadows. Such compressional features should occur at a left step in a right-lateral fault system.

\section{REFERENCES AND SELECTED SOURCES OF GEOLOGIC INFORMATION}

Albers, J.P., 1967, Belt of sigmoidal bending and right-lateral faulting in the western Great Basin: Geological Society of America Bulletin, v. 78, p. 143-156.

(HQS.880517.2602)

Albers, J.P., and Stewart, J.H., 1972, Geology and mineral deposits of Esmeralda County, Nevada: Nevada Bureau of Mines and Geology, Bulletin 78, 80 p., scale 1:250,000. (HQS.880517.1904)

Burchfiel, B.C., Hamill, G.S., IV, and Wilhelms, D.E., 1983, Structural geology of the Montgomery Mountains and the northern half of the Nopah and Resting Spring Ranges, Nevada and California: Geological Society of America Bulletin, v. 94, p. 1359-1376. (NNA.900614.0547)

Cornwall, H.R., 1972, Geology and mineral deposits of southern Nye County, Nevada: Nevada Bureau of Mines and Geology, Bulletin 77, 49 p., scale 1:250,000. (HQS.880517.1128)

Drewes, Harald, 1963, Geology of the Funeral Peak quadrangle, California, on the east flank of Death Valley: U.S. Geological Survey Professional Paper 413, 78 p., scale 1:62,500. (NNA.900614.0533)

Ekren, E.B., 1968, Geologic setting of Nevada Test Site and Nellis Air Force Range, in Eckel, E.B., ed., Nevada Test Site: Geological Society of America Memoir 110, p. 11-20._(HQS.880517.1179) 
Fox, K.F., Jr., and Carr, M.D., 1989, Neotectonics and volcanism at Yucca Mountain and. vicinity, Nevada, in Radioactive Waste Management and the Nuclear Fuel Cycle, v. 13: Harwood Academic Publishers, p. 37-50. (NNA.900614.0534)

Gianella, V.P., and Callaghan, Eugene, 1934, The earthquake of Dec. 20, 1932, at Cedar Mountain, Nevada, and its bearing on the genesis of basin range structure: Journal of Geology, v. 42, p. 1-22. (HQS.880517.1230)

Hamilton, R.M., Smith, B.E., Fischer, F.G., and Papanek, P.J., 1972, Earthquakes caused by underground nuclear explosions on Pahute Mesa, Nevada Test Site: Bulletin of the Seismological Society of America, v. 62, p. 1319-1341. (HQS.880517.1248)

Hamilton, W.B., 1988, Detachment faulting in the Death Valley region, California and Nevada, in Carr, M.D., and Yount, J.C., eds., Geologic and hydrologic investigations of a potential nuclear waste disposal site at Yucca Mountain, southern Nevada: U.S. Geological Survey Bulletin 1790, p. 51-86.

(NNI.881128.0011)

Hinrichs, E.N., 1968, Geologic map of the Camp Desert Rock quadrangle, Nye County, Nevada: U.S. Geological Survey Geologic Quadrangle Map GQ-726, scale 1:24,000. (NNA.900618.0082)

Hunt, C.B., and Mabey, D.R., 1966, Stratigraphy and structure, Death Valley, California: U.S. Geological Survey Professional Paper 494-A, 162 p., scale 1:96,000. (HQS.880517.0374)

Locke, Augustus, Billingsley, P.R., and Mayo, E.B., 1940, Sierra Nevada tectonic patterns: Geological Society of America Bulletin, v. 51, p. 513-540. (HQS.880517.1321)

McAllister, J.F., 1970, Geology of the Furnace Creek borate area, Death Valley, Inyo County, California: California Division of Mines and Geology, Map Sheet 14, scale 1:24,000. (NNA.900618.0083)

McKittrick, M.A., 1988, Surficial geologic map of the Resting Spring and Nopah Ranges, Inyo County, California, and Nye County, Nevada: U.S. Geological Survey Miscellaneous Field Investigations Map MF-1941, scale 1:62,500. (NNA.900618.0077)

Moring, Barry, 1986, Reconnaissance surficial geologic map of northern Death Valley, California and Nevada: U.S. Geological Survey Miscellaneous Field Studies Map MF-1770, scale 1:62,500. (NNA.900618.0078)

Pexton, R.E., 1984, Geology and paleohydrology of a part of the Amargosa Desert, Nevada: Berkeley, Calif., University of California, M.S. thesis, 63 p. (HQS.880517.1818)

Reheis, M.C., 1988, Preliminary study of Quaternary faulting on the east side of Bare Mountain, Nye County, Nevada, in Carr, M.C., and Yount, J.C., eds., Geologic and hydrologic investigations of a potential nuclear waste disposal site at Yucca Mountain, southern Nevada: U.S. Geological Survey Bulletin 1790, p. 103-112. (NNI.881128.0011) 
Sargent, K.A., and Stewart, J.H., 1971, Geologic map of the Specter Range NW quadrangle, Nye County, Nevada: U.S. Geological Survey Geologic Quadrangle Map GQ-884, scale 1:24,000. (NNA.900618.0079)

Stewart, J.H., 1987, Tectonics of the Walker Lane belt, western Great Basin--Mesozoic and Cenozoic deformation in a zone of shear, in Ernst, W.G., ed., Metamorphism and Crustal Evolution of the Western United States: Rubey Volume VII, Prentice-Hall Inc., New Jersey, p. 683-713. (NNA.900614.0535)

Swadley, W C, 1983, Map showing surficial geology of the Lathrop Wells quadrangle, Nye County, Nevada: U.S. Geological Survey Miscellaneous Geologic Investigations Map I-1361, scale 1:48,000. (HQS.880517.1513)

Swadley, W C, and Carr, W.J., 1987, Geologic map of the Quaternary and Tertiary deposits of the Big Dune quadrangle, Nye County, Nevada, and Inyo County, California: U.S. Geological Survey Miscellaneous Geologic Investigations Map I-1767, scale 1:48,000. (NNA.900618.0080)

Swadley, W C, Hoover, D.L., and Rosholt, J.N., 1984, Preliminary report on late Cenozoic faulting and stratigraphy in the vicinity of Yucca Mountain, Nye County, Nevada: U.S. Geological Survey Open-File Report 84-788, 42 p., scale 1:62,500. (HQS.880517.1515)

Swadley, W C, and Parrish, L.D., 1988, Surficial geologic map of the Bare Mountain quadrangle, Nye County, Nevada: U.S. Geological Survey Miscellaneous Geologic Investigations Map I-1826, scale 1:48,000. (NNA.900618.0081)

Zoback, M.L., and Zoback, M.D., 1980, State of stress in the conterminous United States: Journal of Geophysical Research, v. 85, no. B11, p. 6113-6156. (HQS.880517.1587)

\section{DISCLAIMER}

This report was prepared as an account of work sponsored by an agency of the United States Government. Neither the United States Government nor any agency thereof, nor any of their employees, makes any warranty, express or implied, or assumes any legal liability or responsibility for the accuracy, completeness, or usefulness of any information, apparatus, product, or process disclosed, or represents that its use would not infringe privately owned rights. Reference herein to any specific commercial product, process, or service by trade name, trademark, manufacturer, or otherwise does not necessarily constitute or imply its endorsement, recommendation, or favoring by the United States Government or any agency thereof. The views and opinions of authors expressed herein do not necessarily state or reflect those of the United States Government or any agency thereof. 


\section{MAP SYMBOLS}

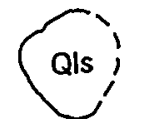

Quaternary landslide deposit. Symbol queried where uncertain. Contact dashed where inferred

Lineament--Dots connect linear features interpreted to be related.

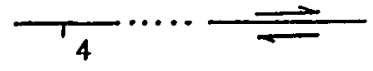
Bar indicates facing direction of scarp. Arrows show inferred direction of strike-slip motion. Number indicates:

0 Topographic lineament, either bounding a linear range front or, rarely, within bedrock

1-4 Lineament or scarp in Quaternary deposits; number increases with prominence of lineament

6-9 Lineament or scarp in Tertiary deposits; number increases with prominence of lineament

Fault--dashed where inferred, dotted where concealed. Bar indicates downthrown side. Arrows show direction of strike-slip motion. Number indicates:

Fault in Quaternary deposits identified from previous mapping; generally equivalent in prominence to lineaments number 3 or 4

Fault in Tertiary deposits identified from previous mapping; generally equivalent in prominence to lineaments numbered 8 or 9 


\section{Department of the Interior U.S. Geological Survey}

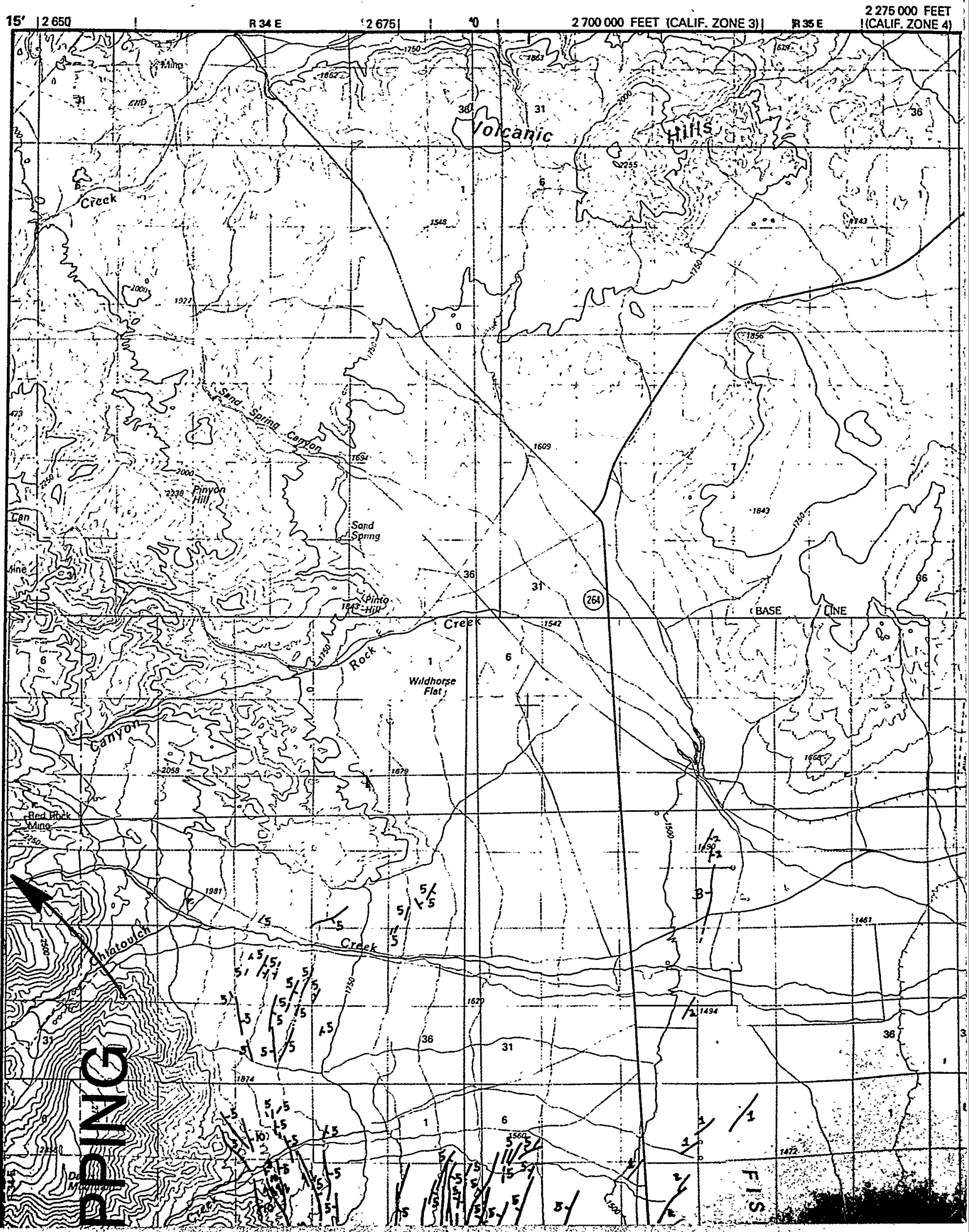




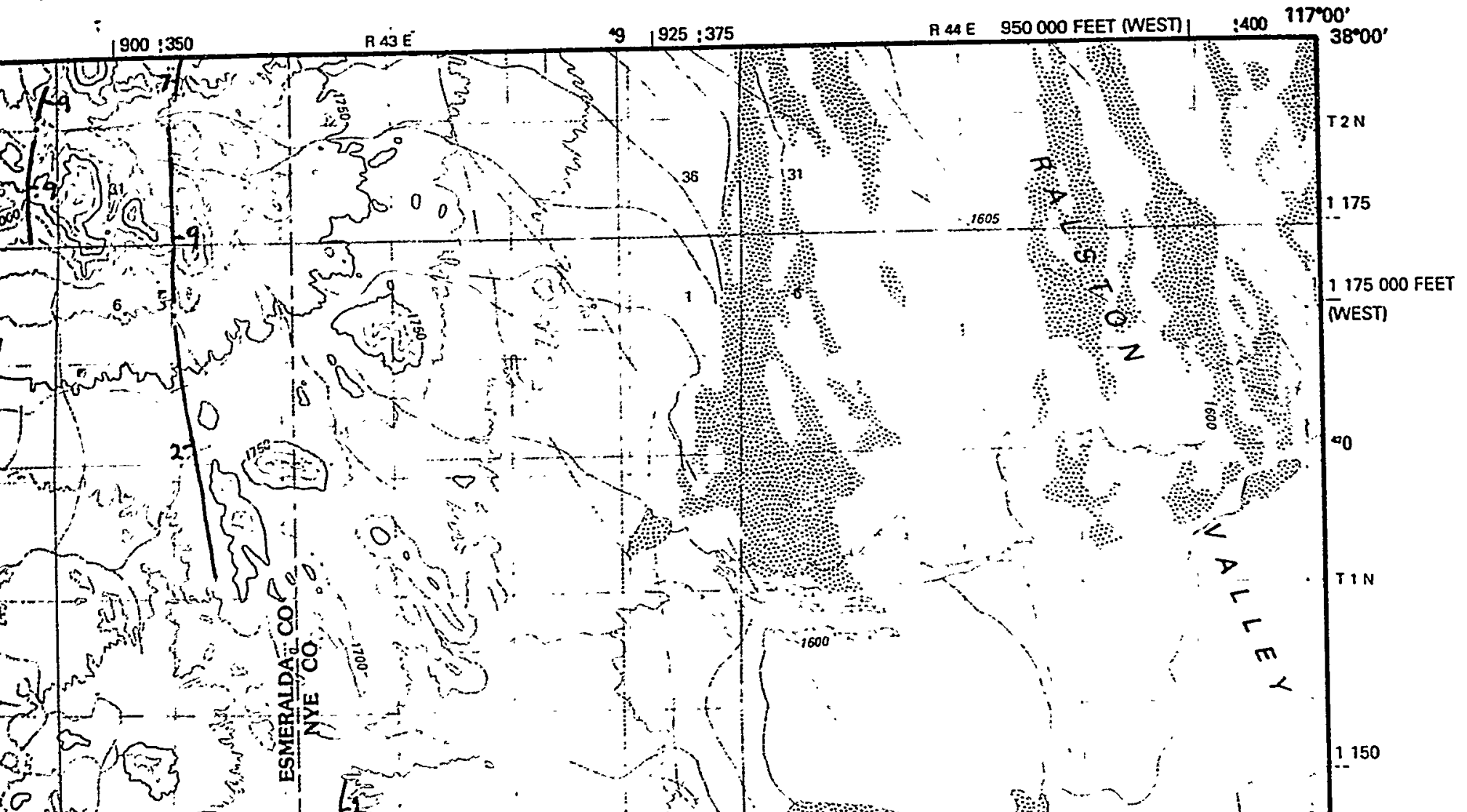




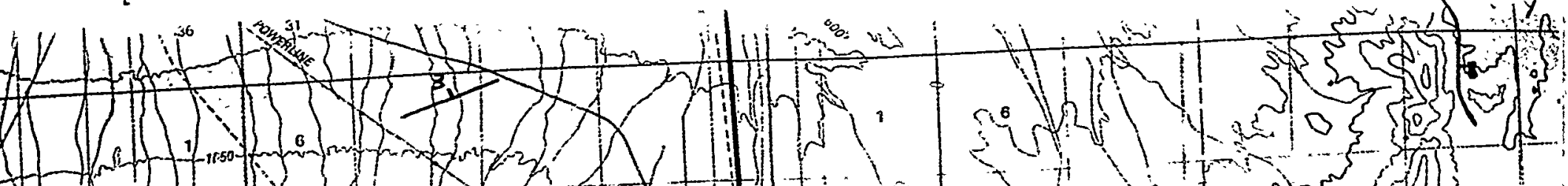

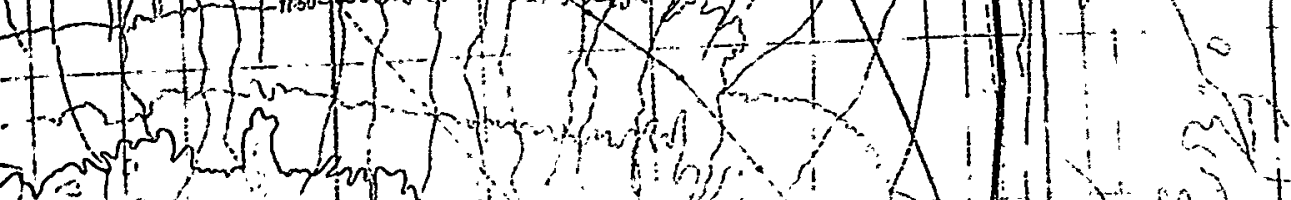
(1) (1) (2)
ris (2) coplozima 1) 


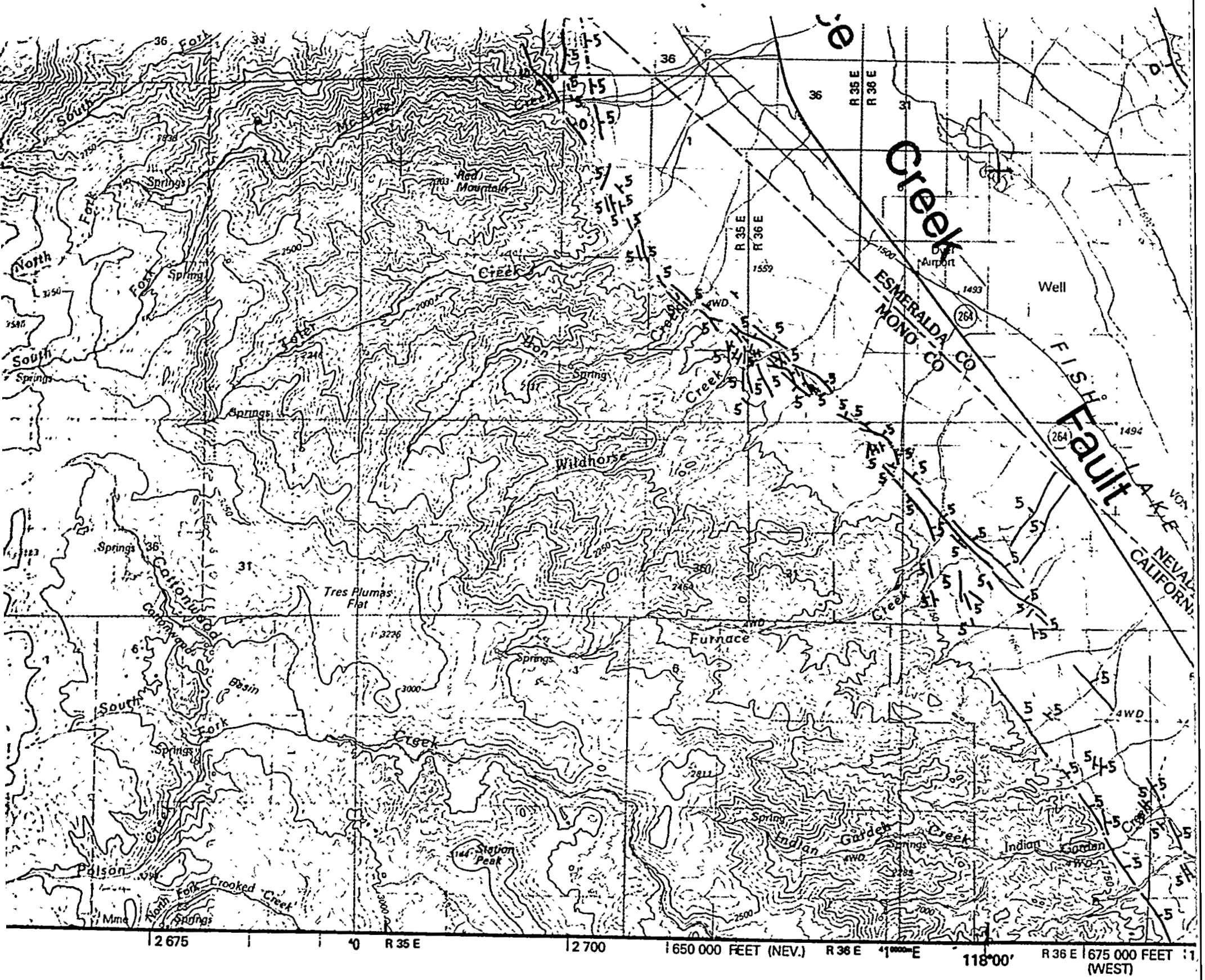

inary and has not been reviewed

J.S. Geological Survey editorial

phic nomenclature

Lineaments 


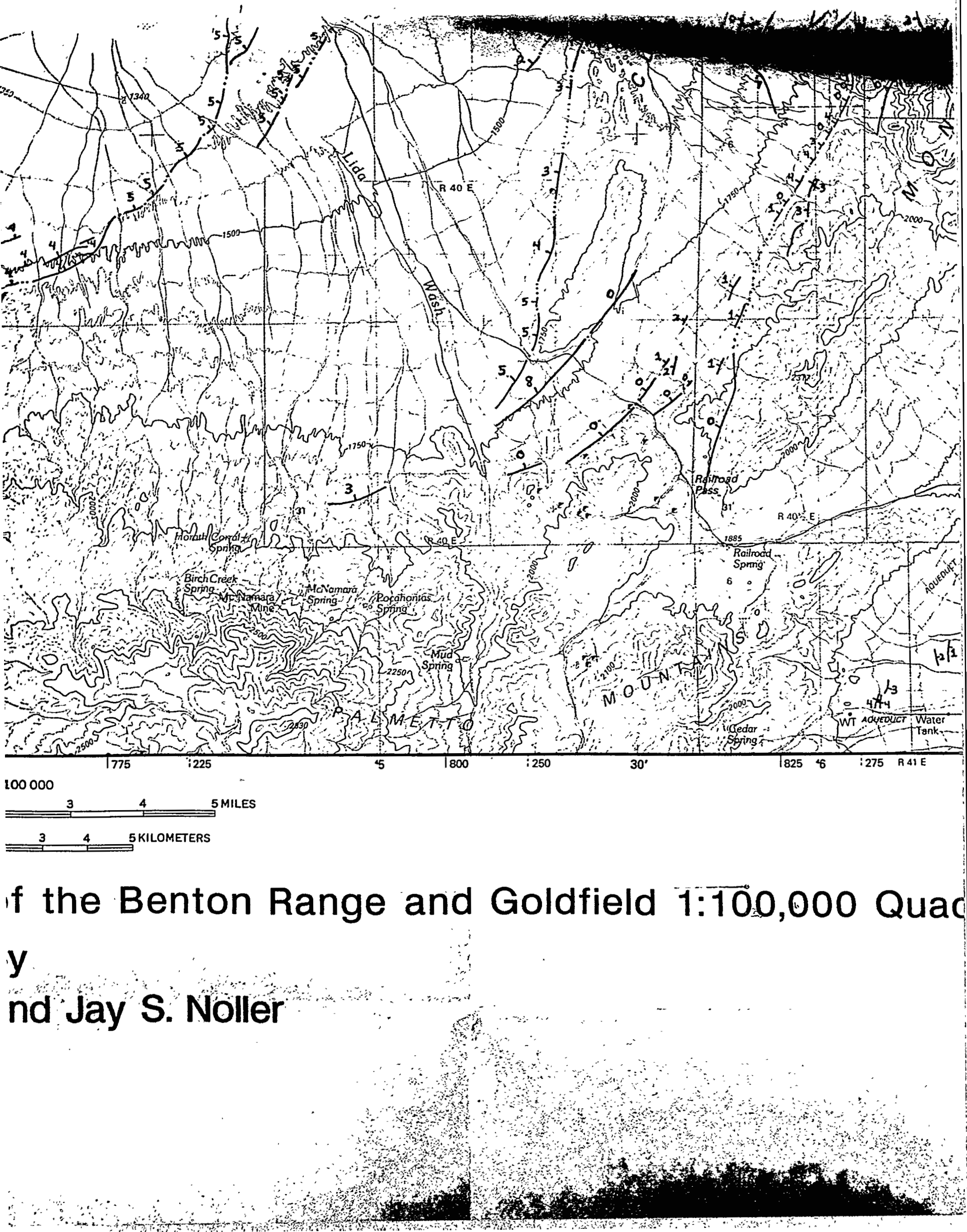




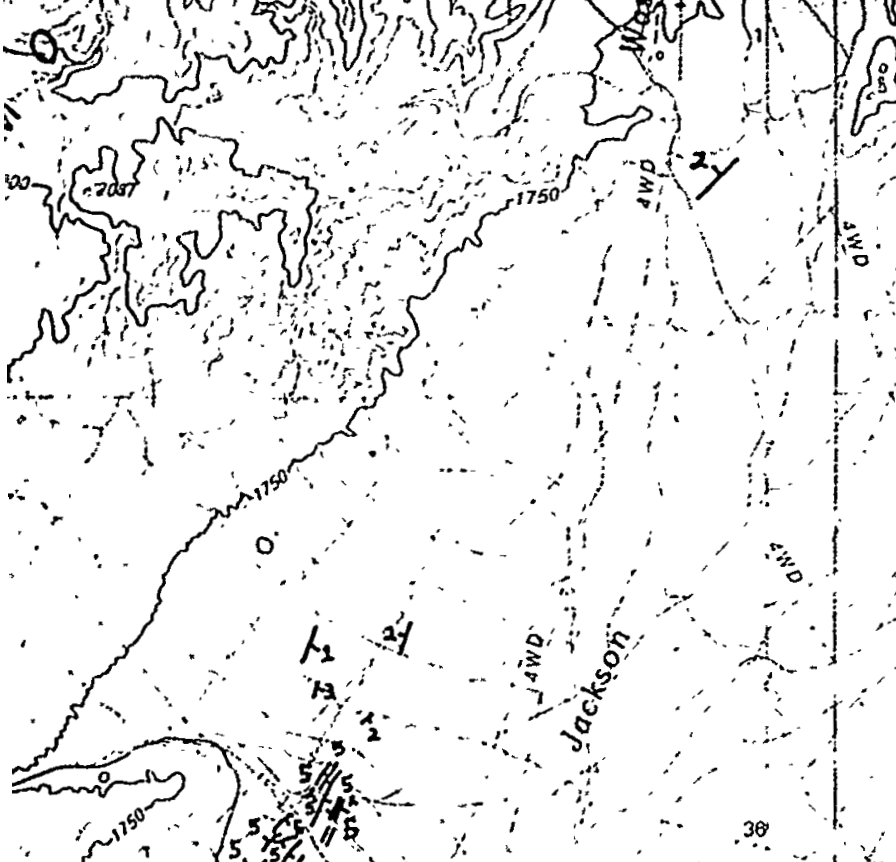

fon

3500

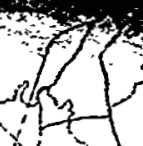

(2)

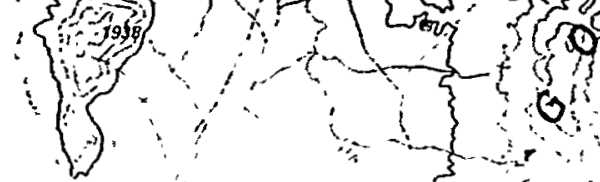

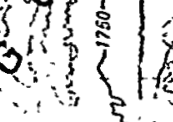

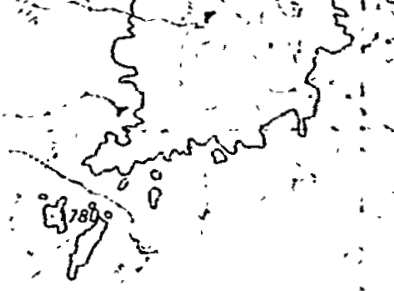

$\int_{3}^{5}{ }^{5}$

ats
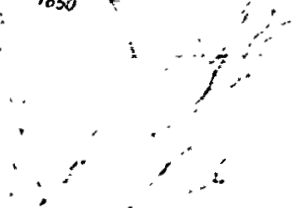

.

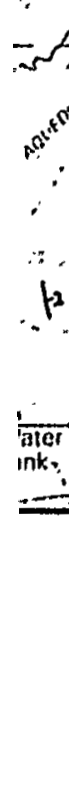

\section{adrangles, California-Nevada}

Base from U.S.G.S.: 


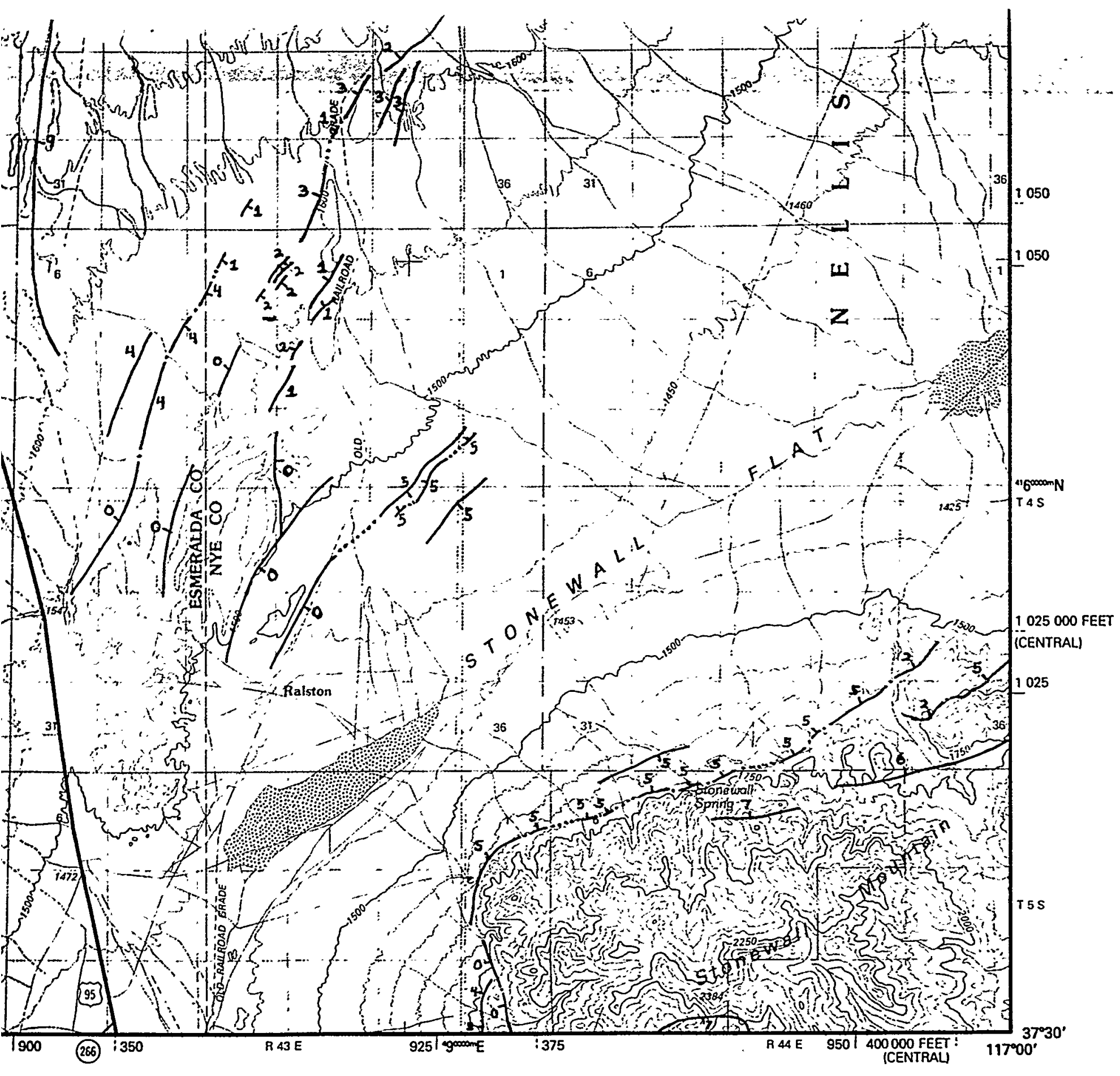

om U.S.G.S. Goldfield 1:100,000, 1985 and U.S.G.S. Benten Range 1:100,000, 1988

Air-photo interpretation by J.S. Noller and M.C. Reheis 1987-1989 


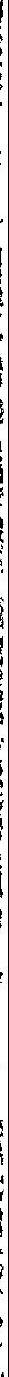

(2) 2. (1) 


\section{Prepared in cooperation with U.S. Department of Energy}

5 800: 2425! 250 R $40 \mathrm{E}$

825: 2450 :275 RA1E

850: $2475 \div \quad 1300$ क) (Lي:3 $=\left(4 b_{E} R\right.$ ? P E A K K OAL $L$ M

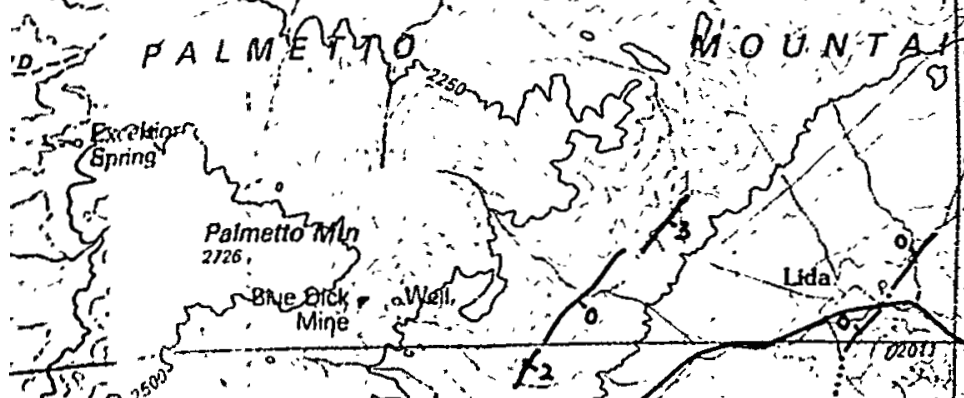

\section{Dis}

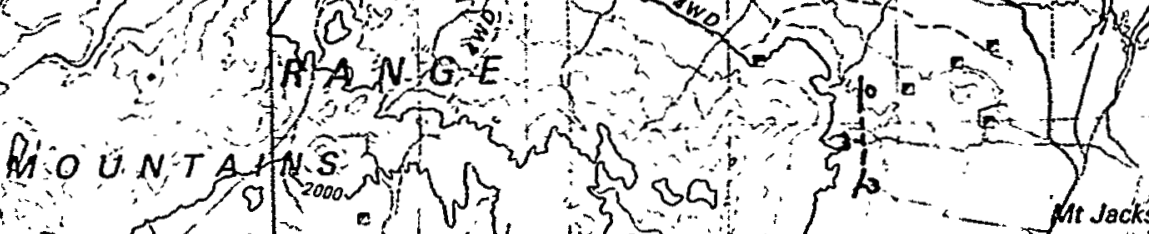

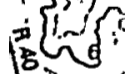
(1)
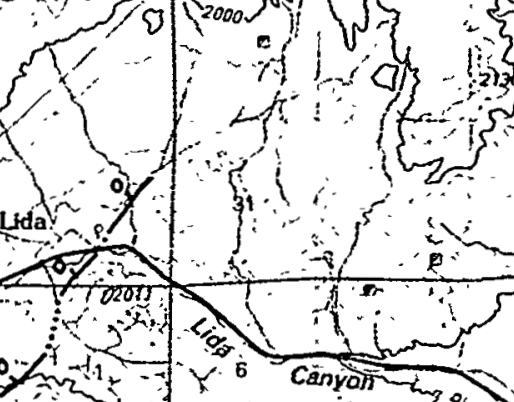

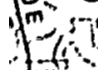
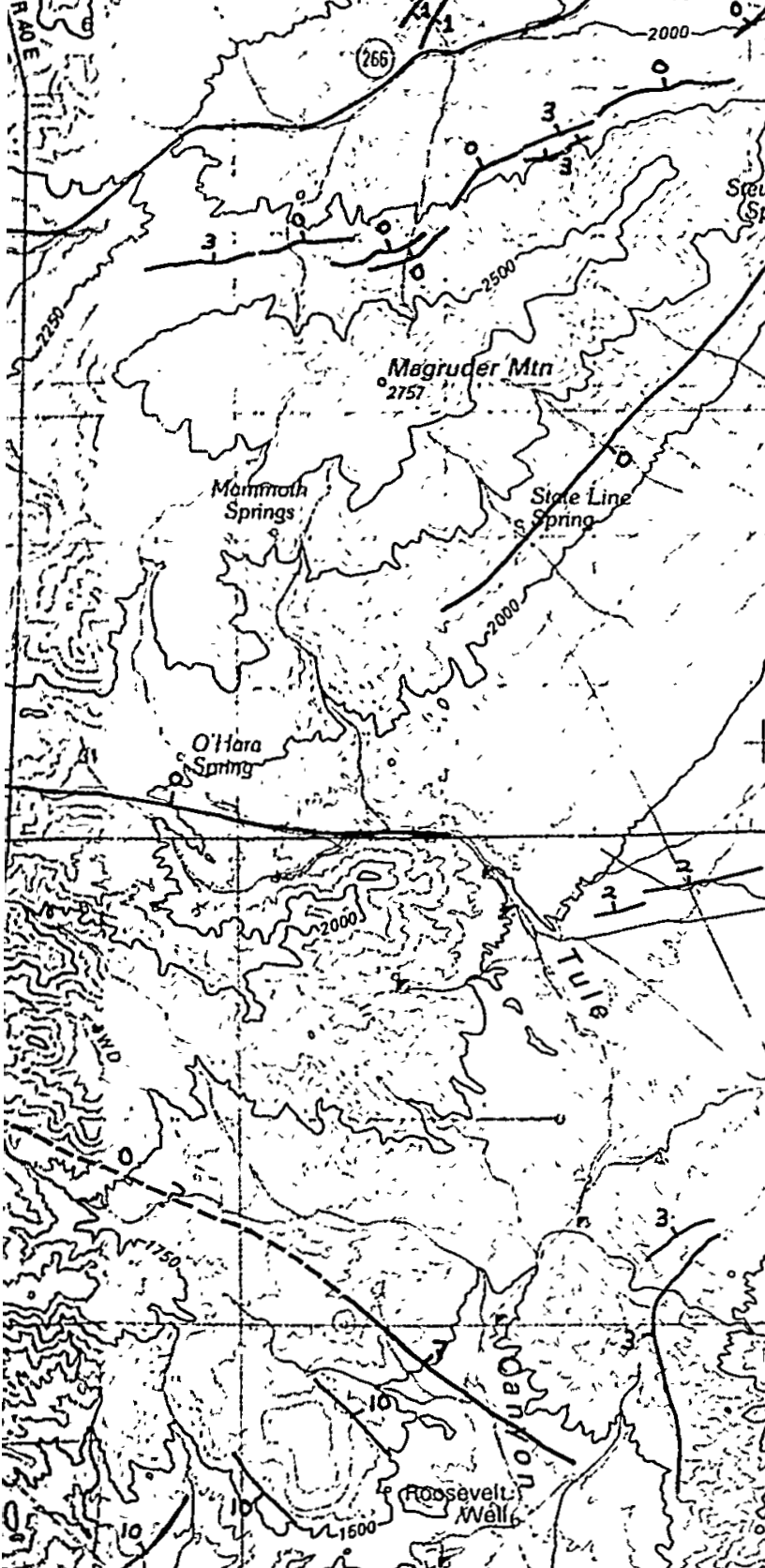

$3:-10$
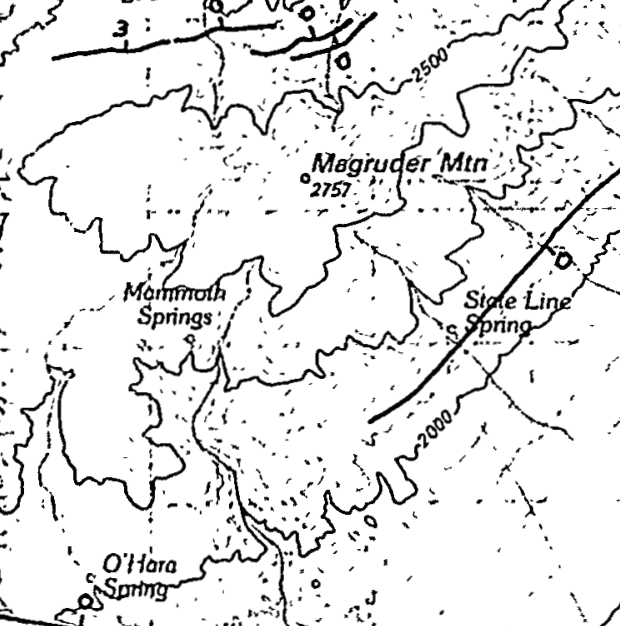

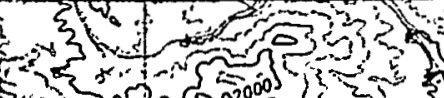
5
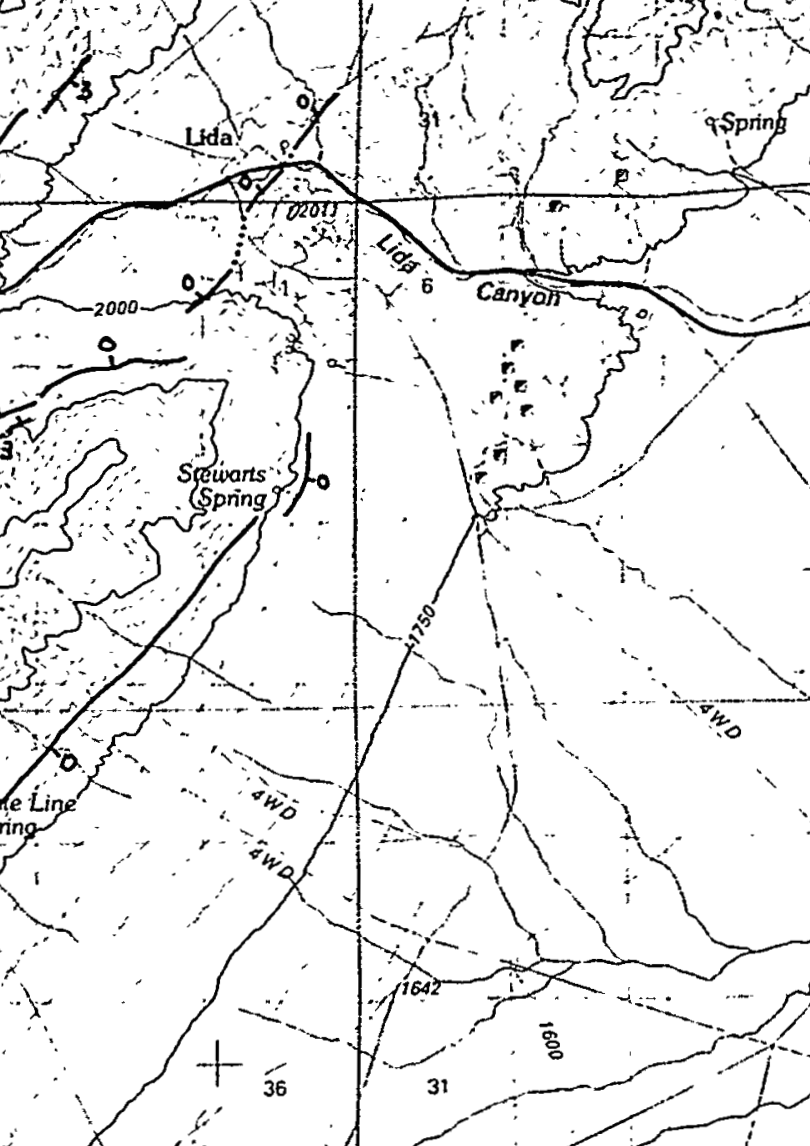


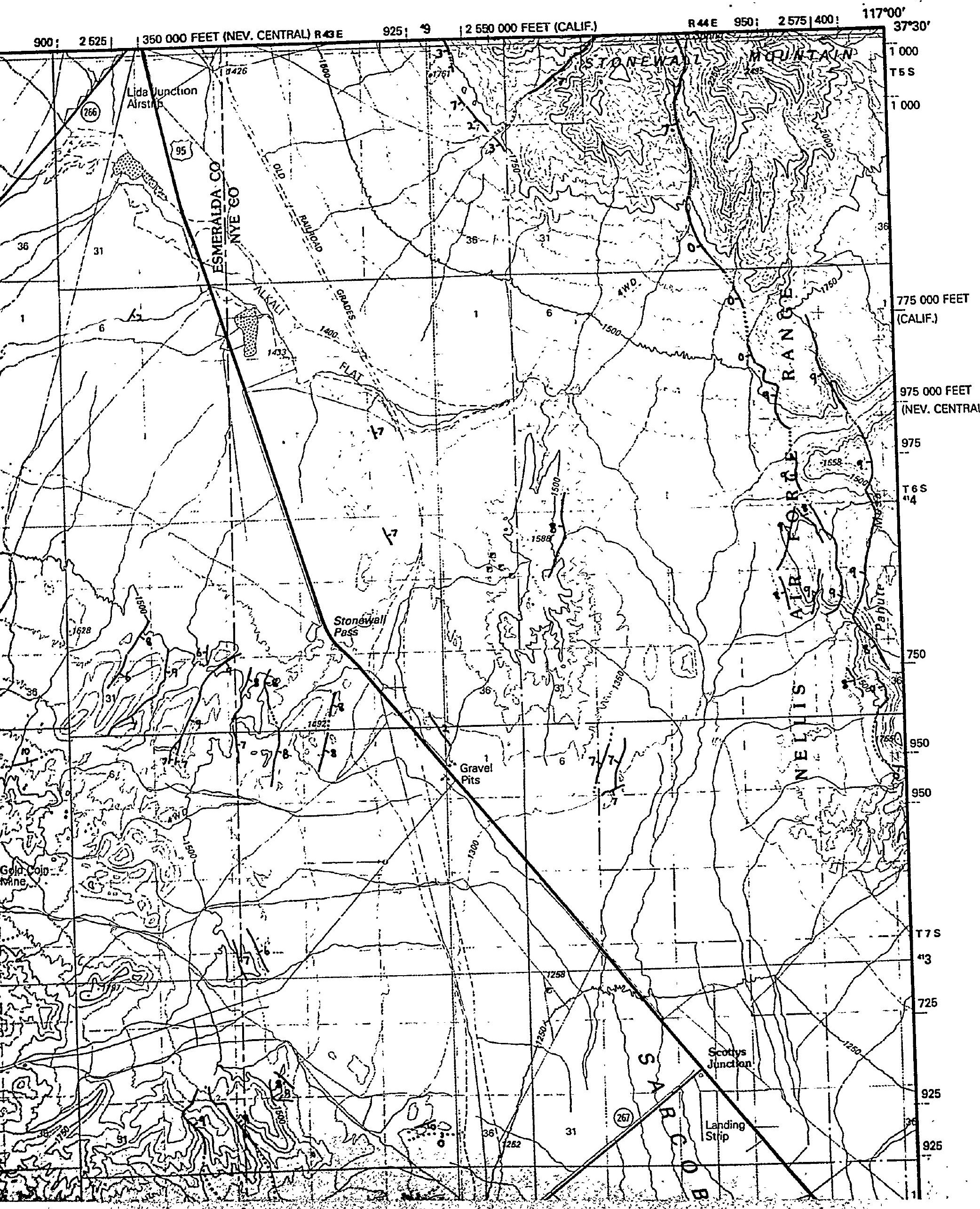




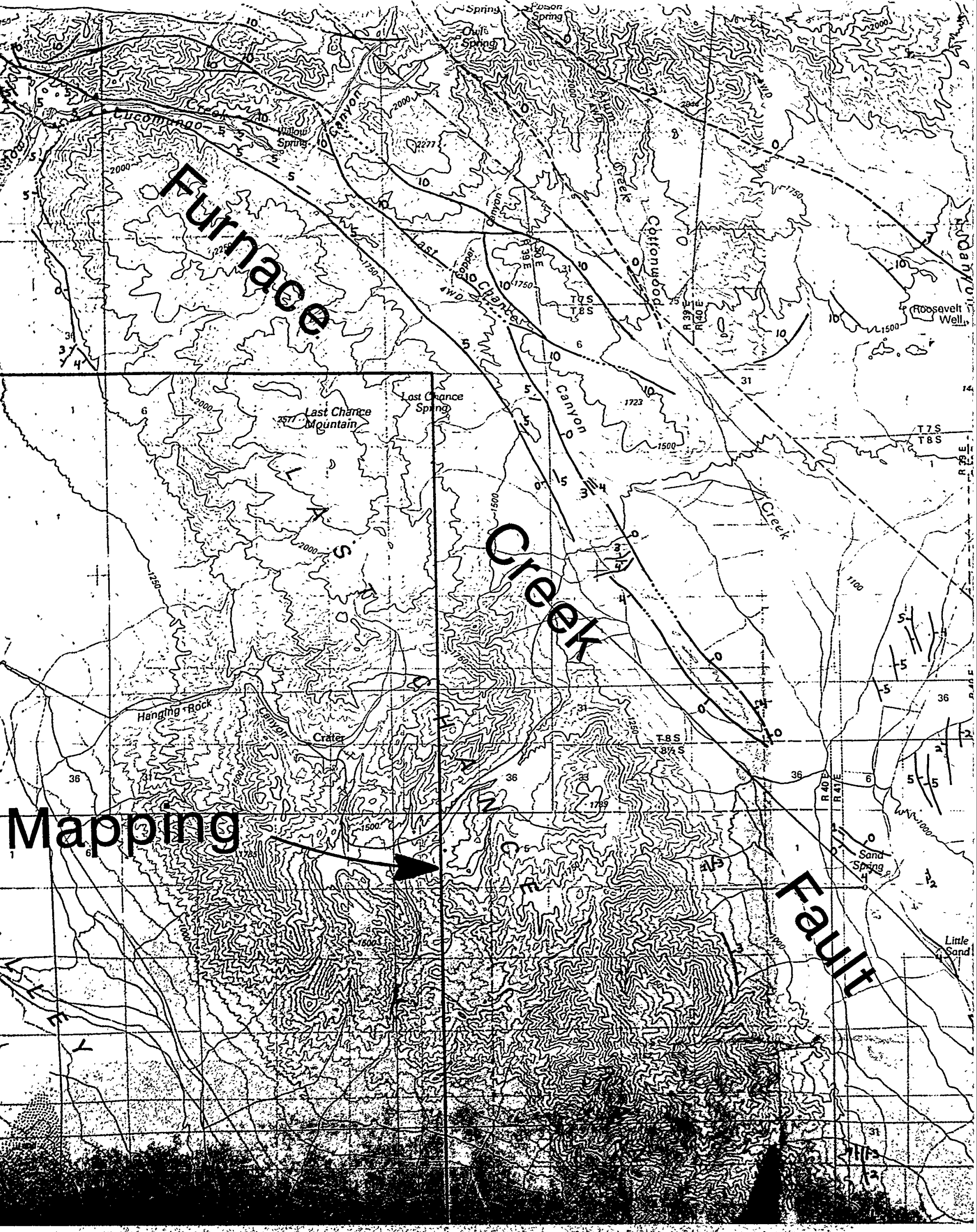


Sints

4.

(n)

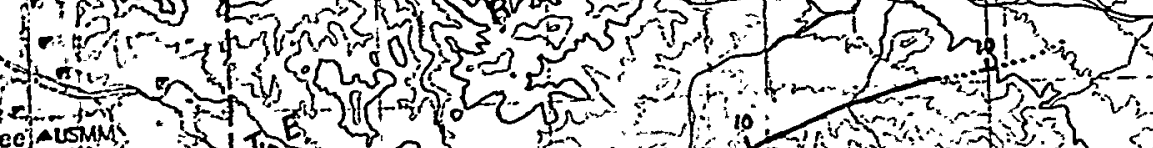

年 है?

is

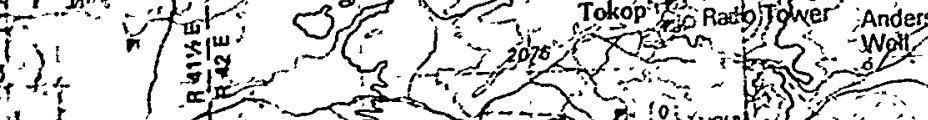

(n) (1)

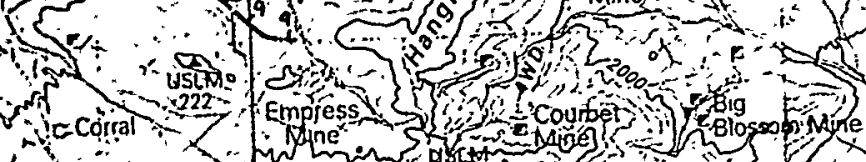
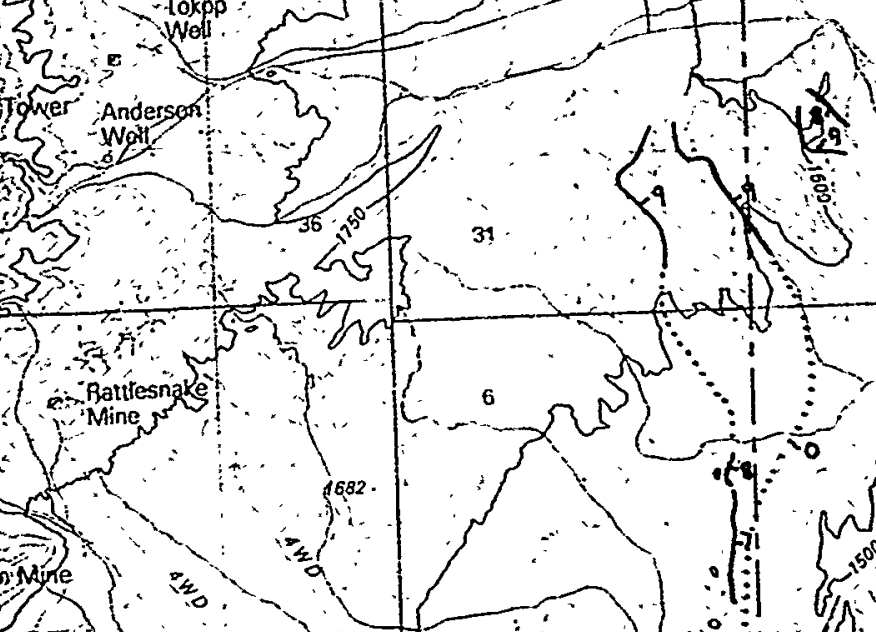

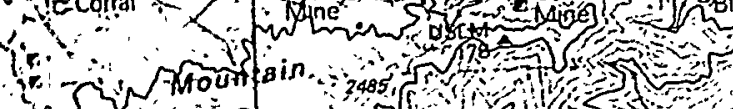

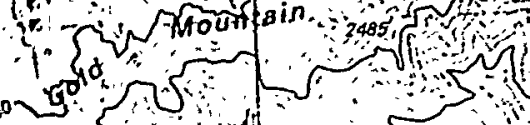

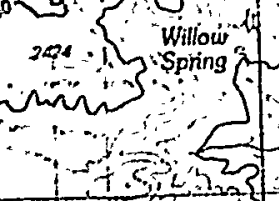

$=3$
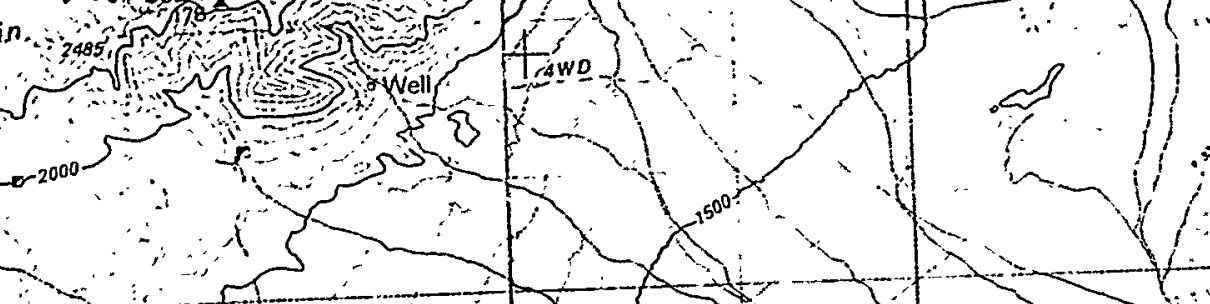

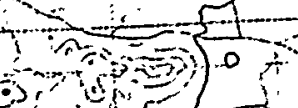

$3-5 \leq 20$

\%

5

$3 \sqrt[3]{5}]$

(1)

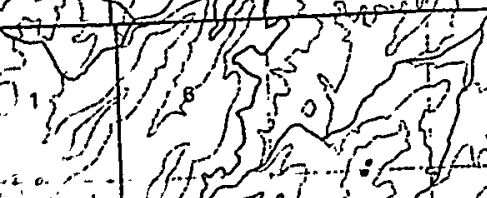

(1)

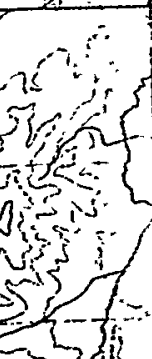

क)
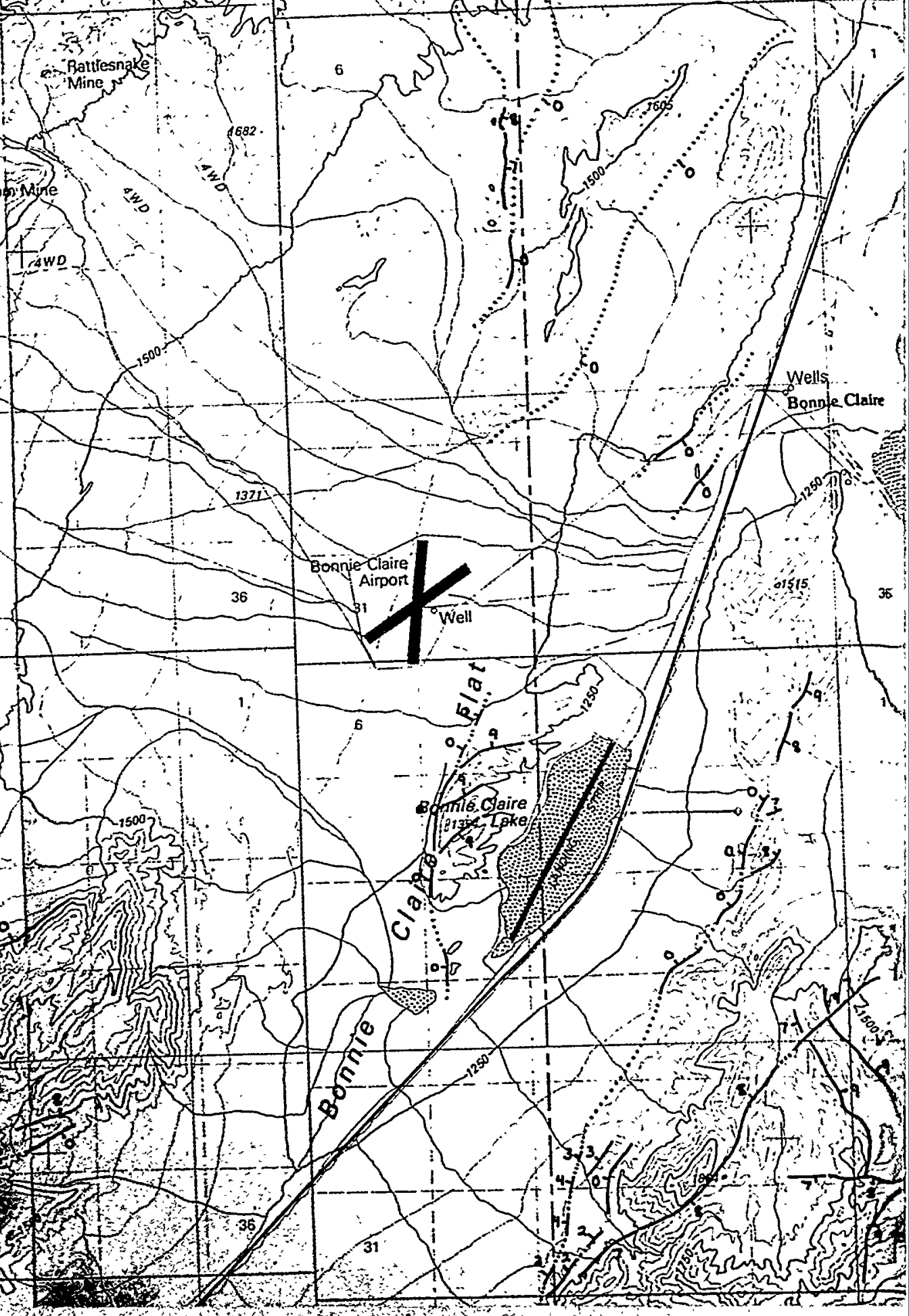


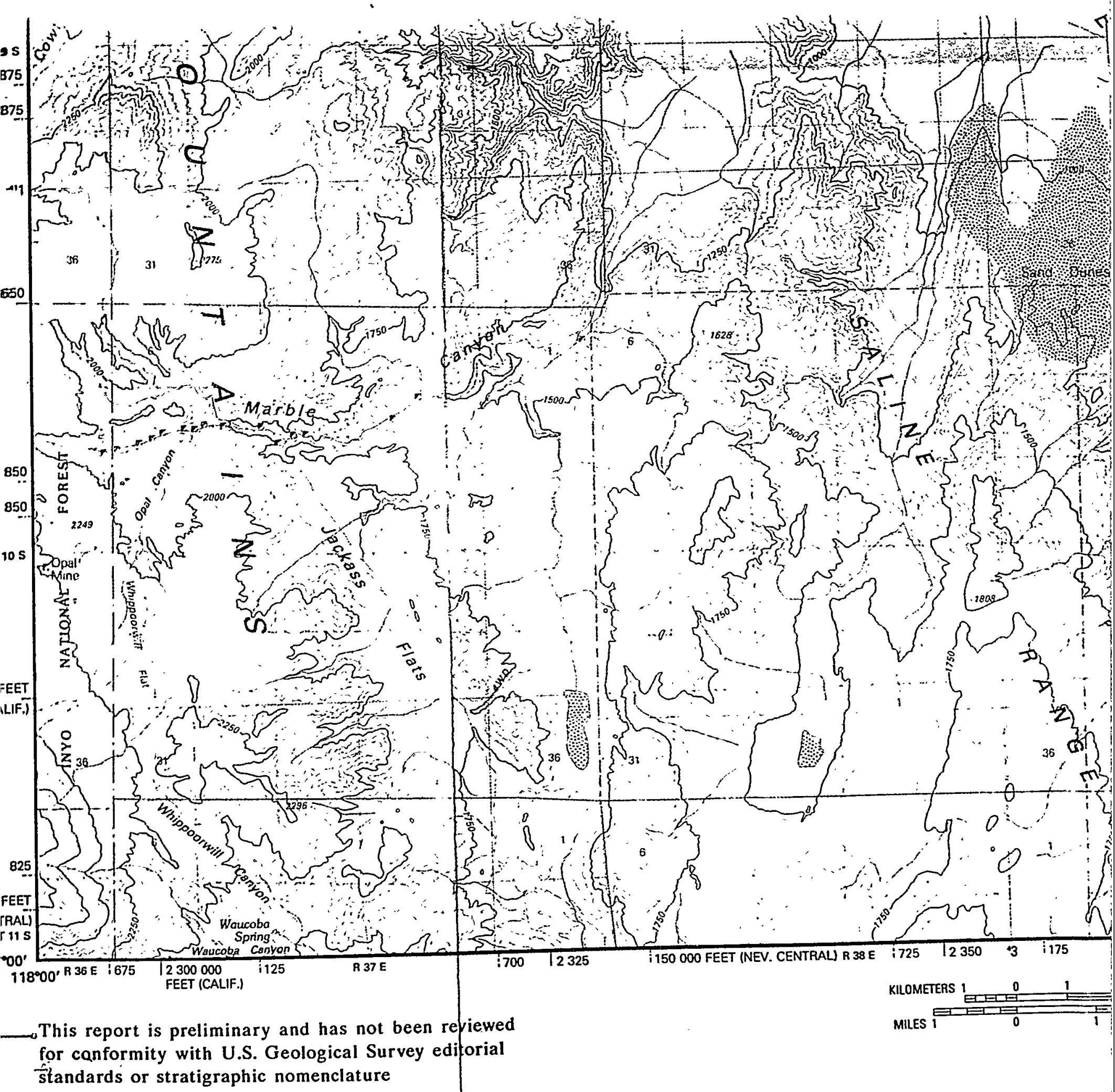




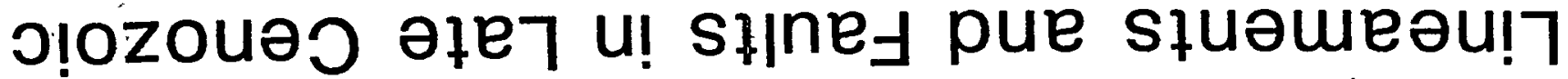

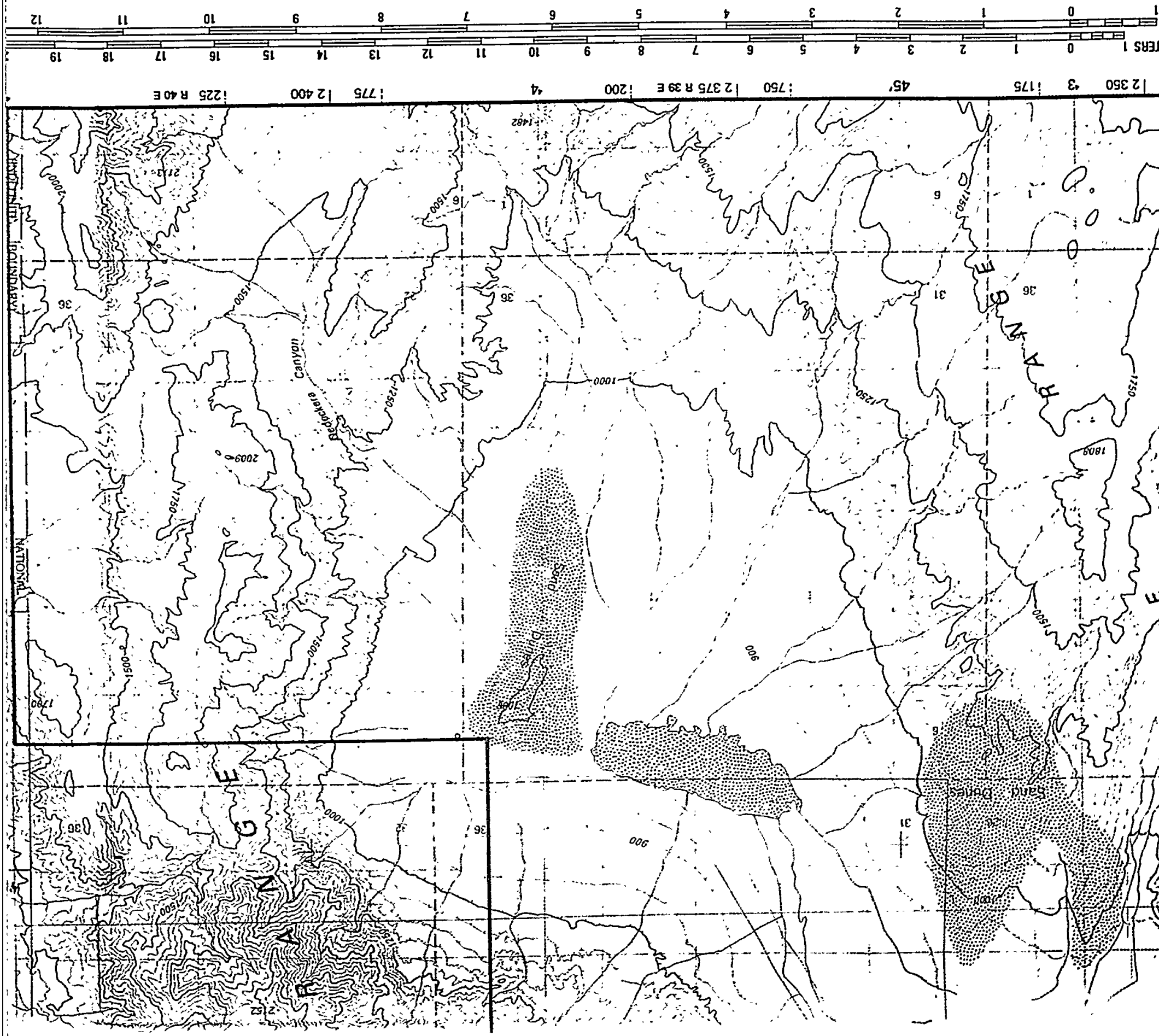




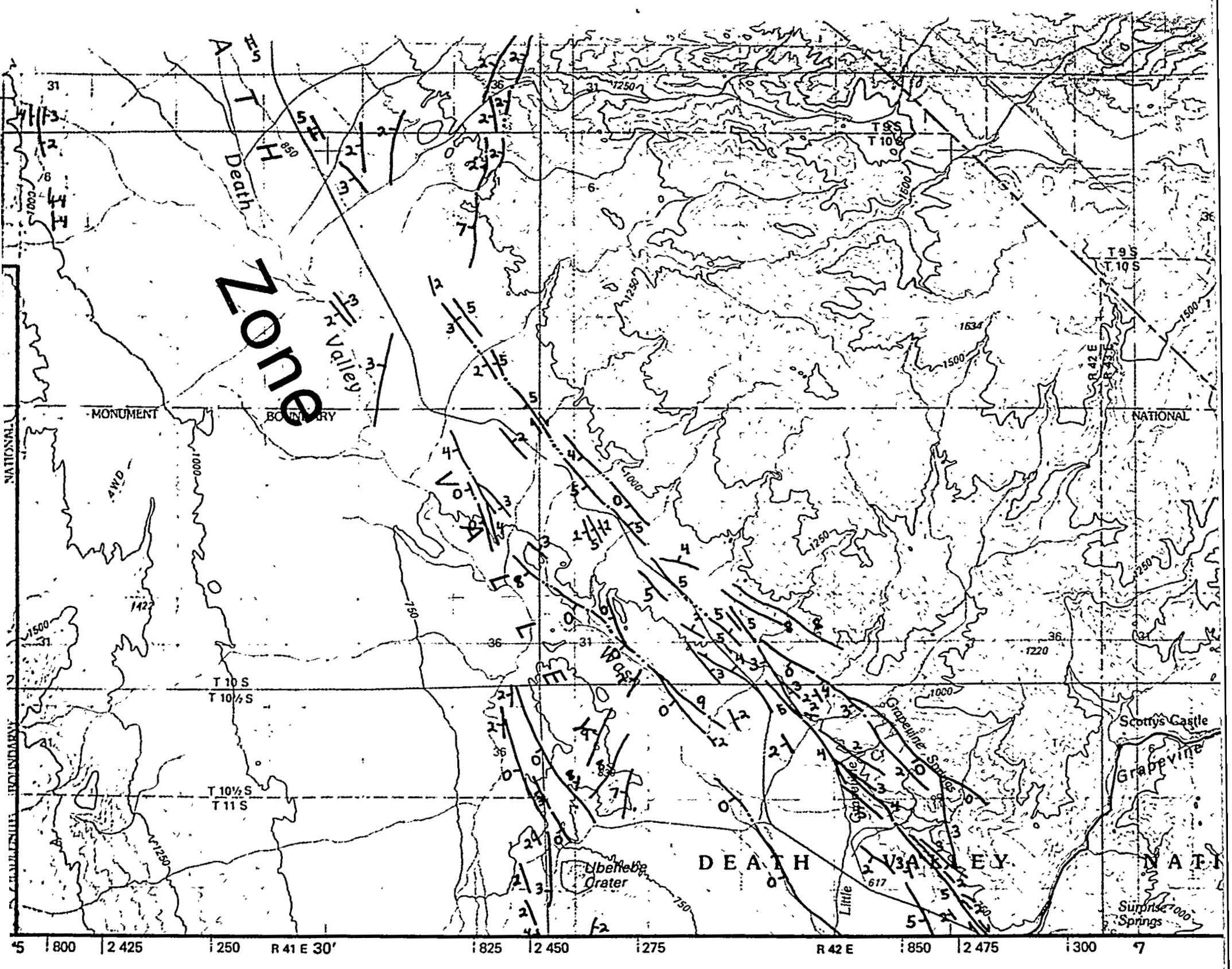




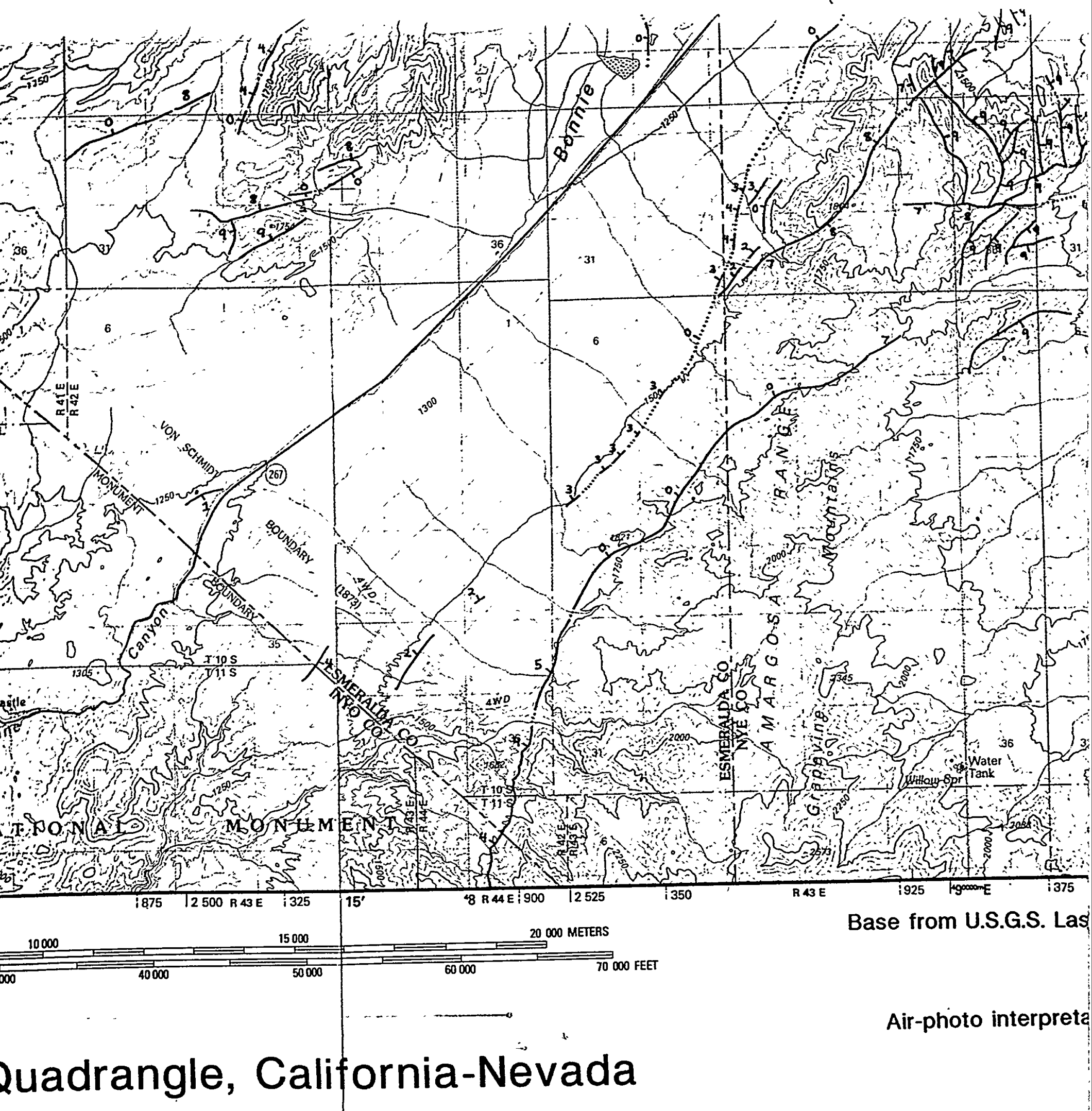




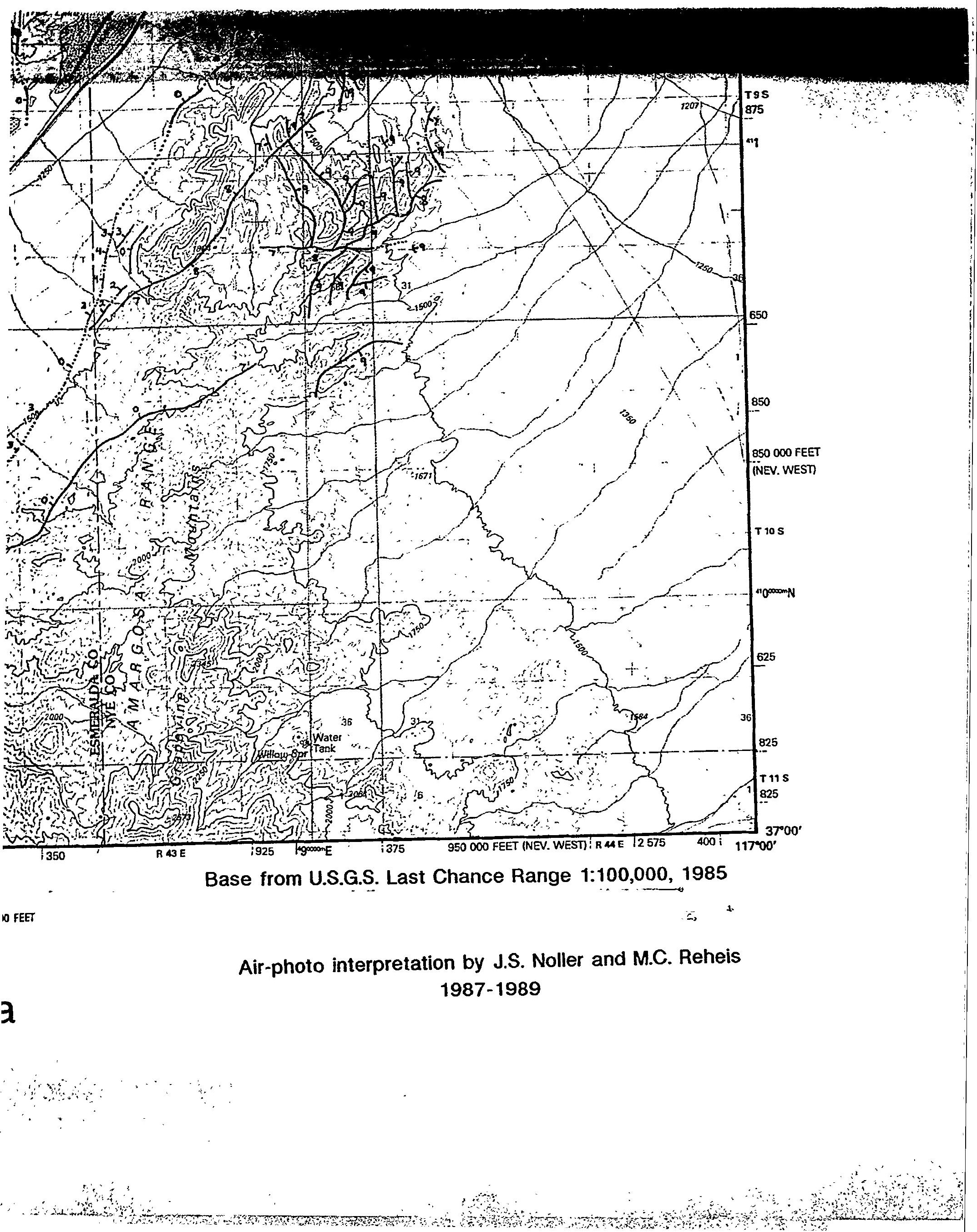




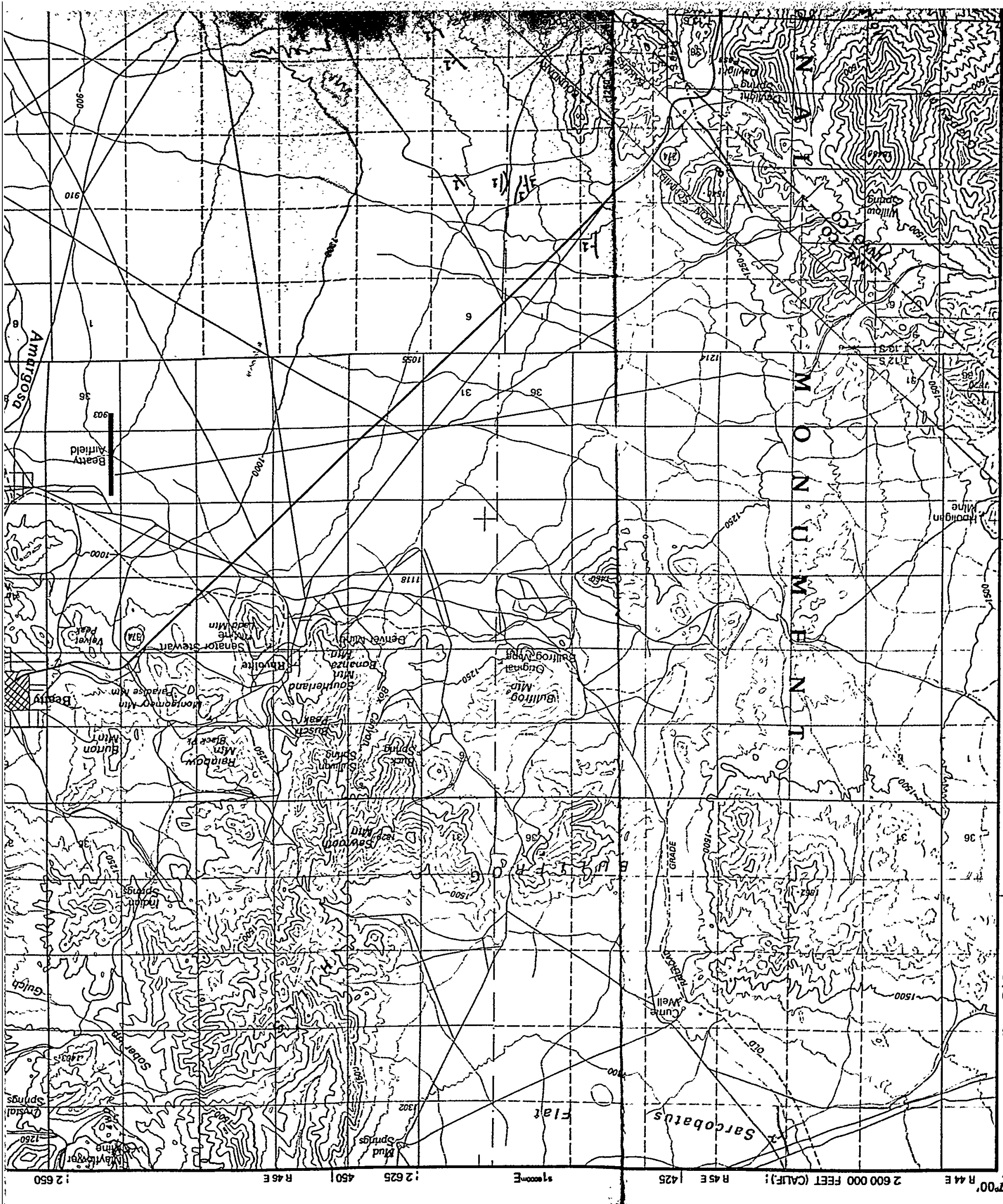




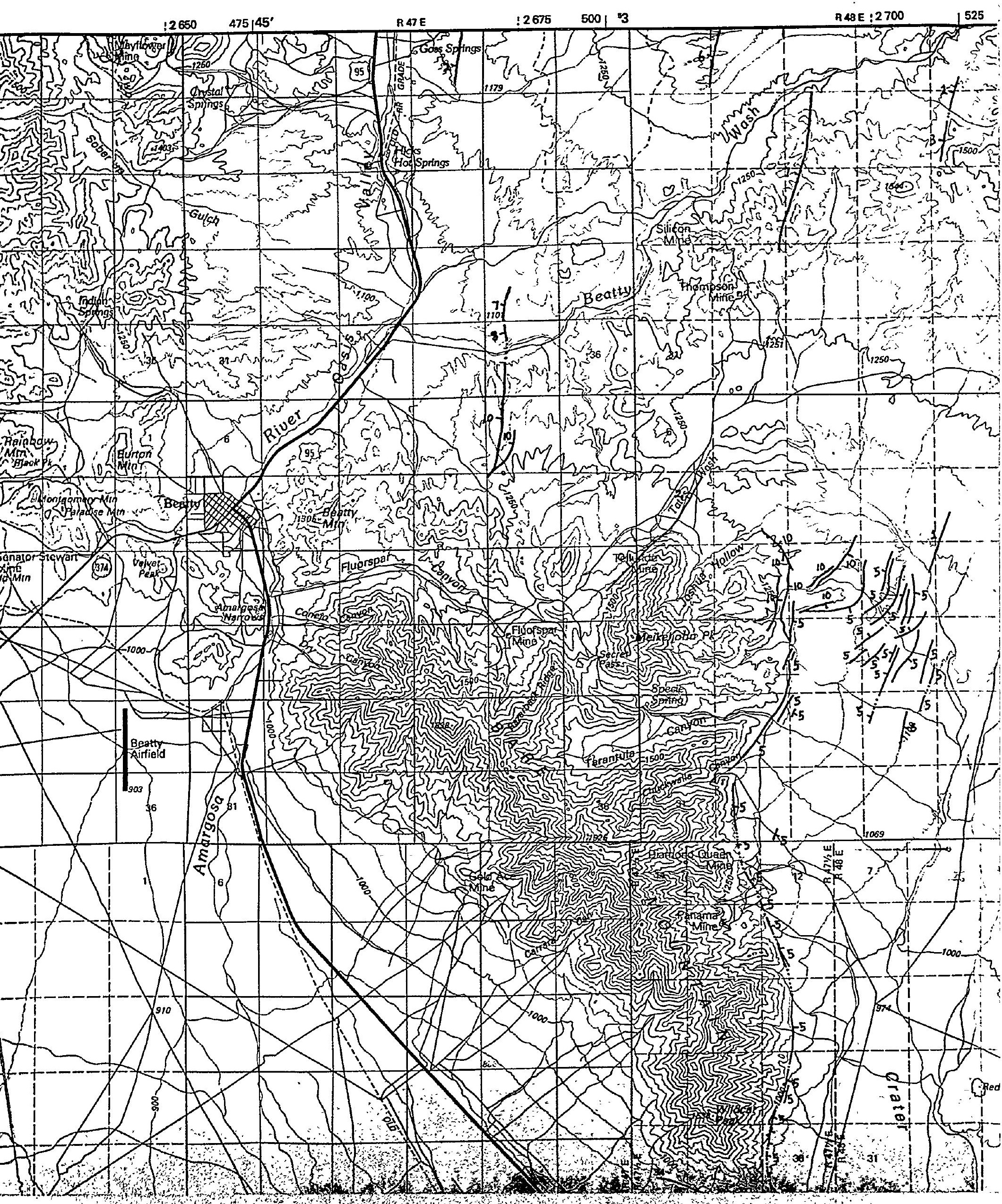




\section{Prepared in cooperation with U.S. Department of Energy}

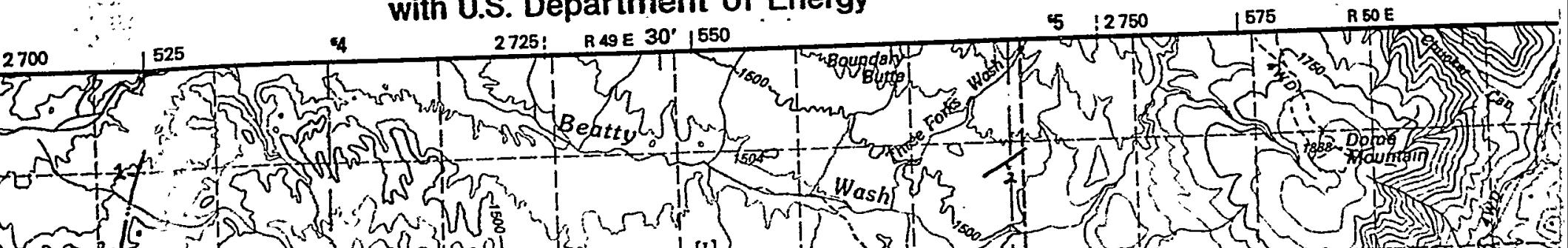

ñ

(5)

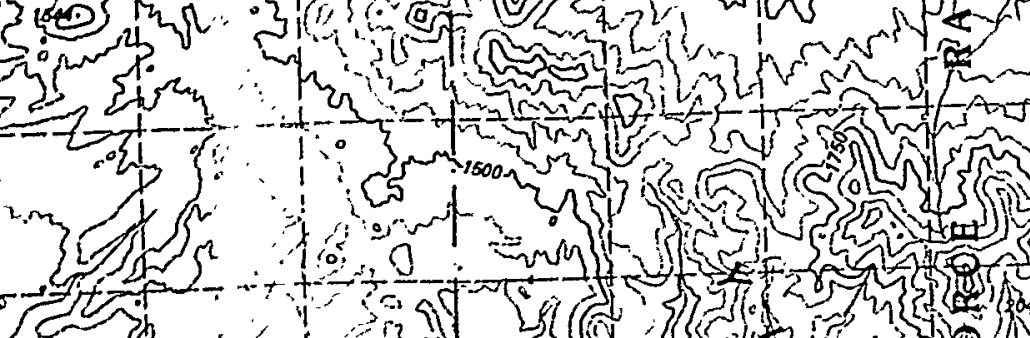
\&ni. 23,

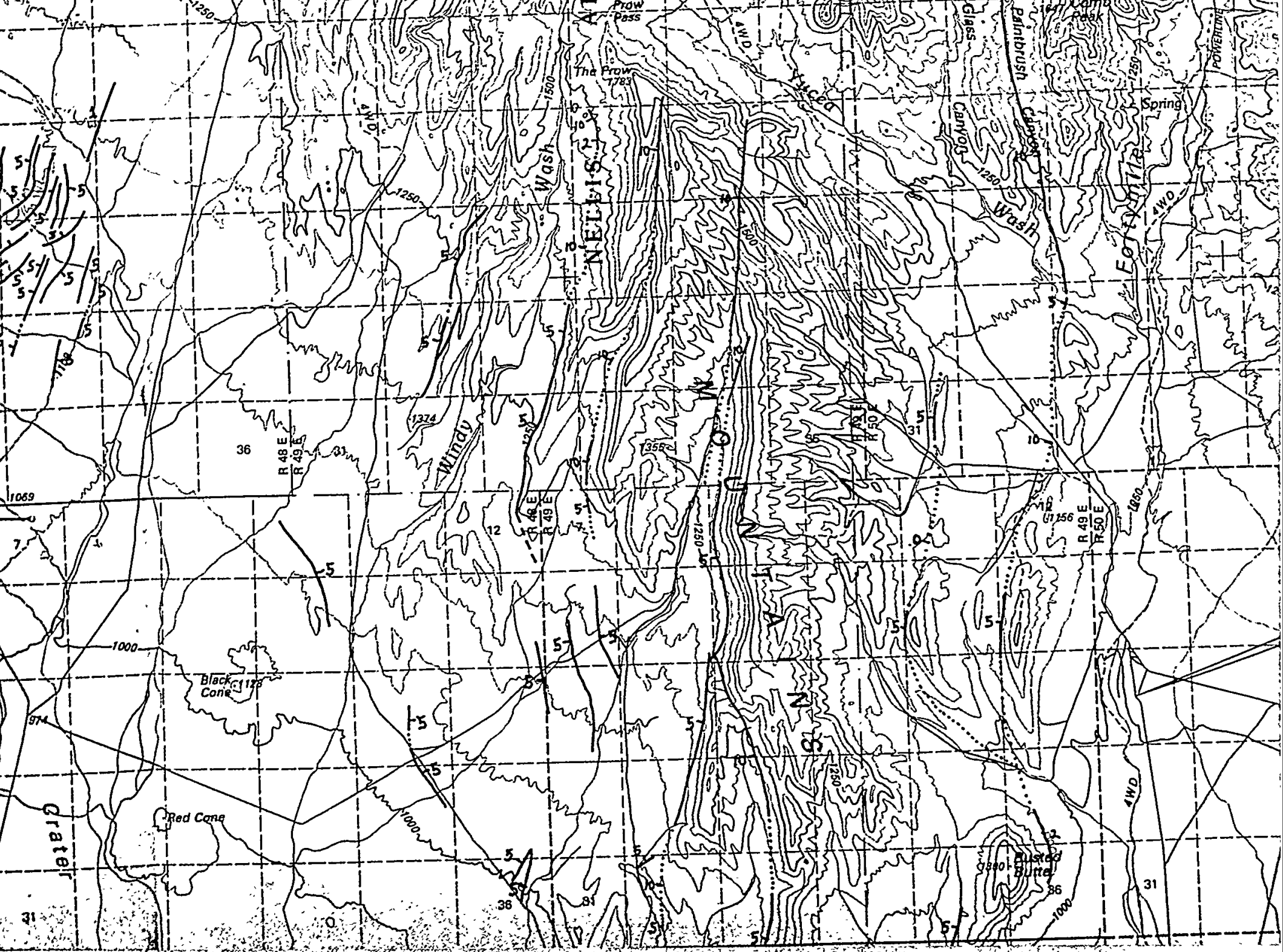




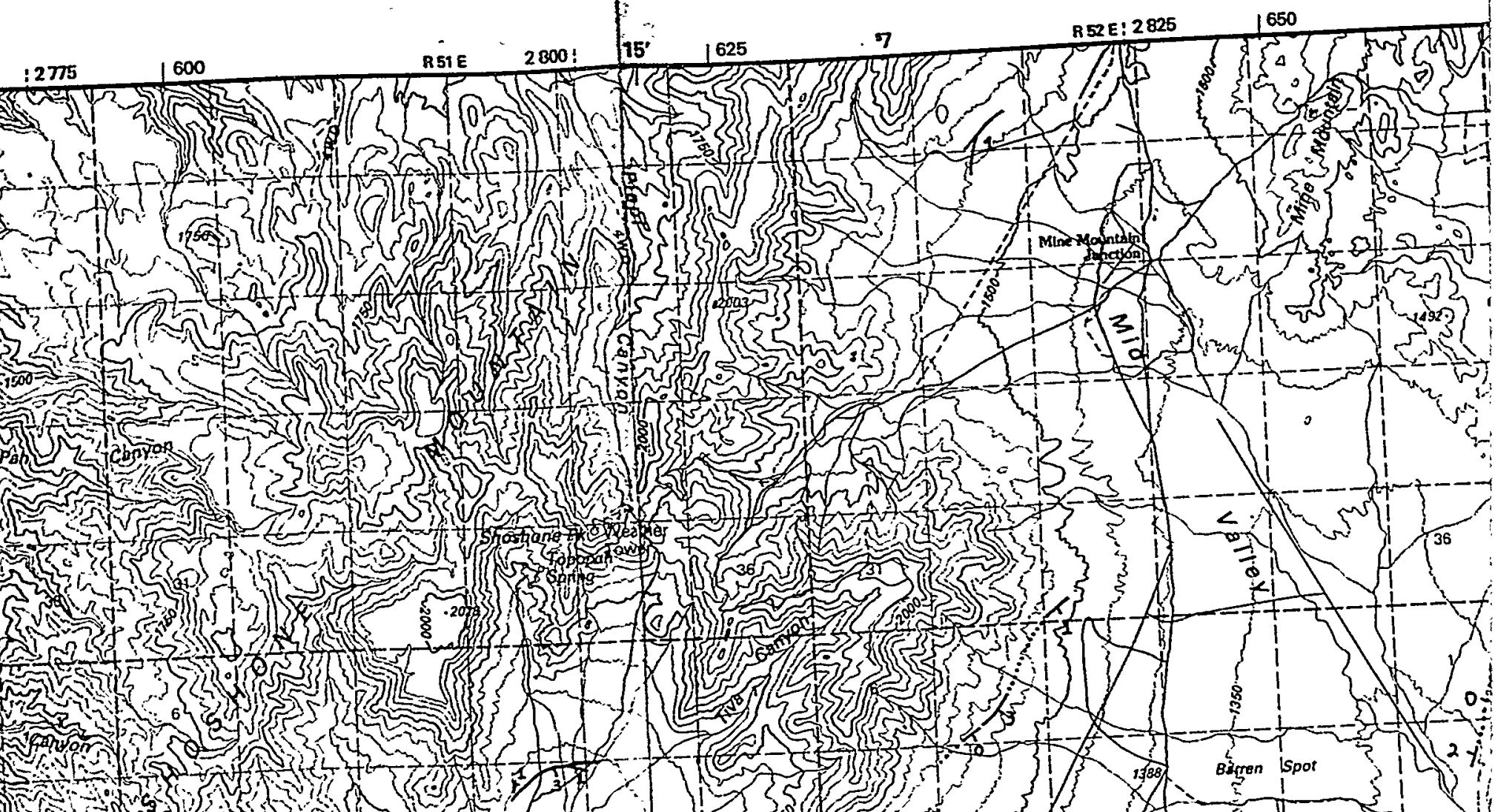

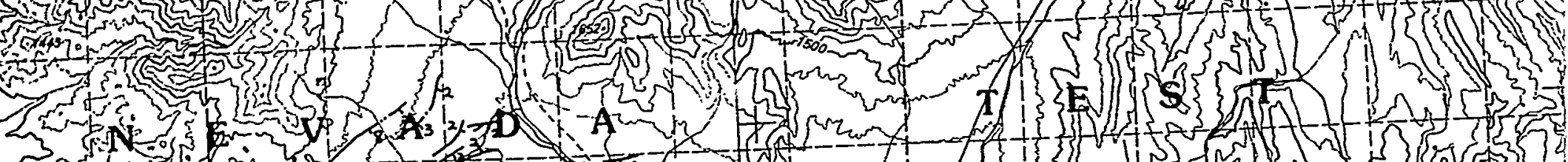
2. (1) 


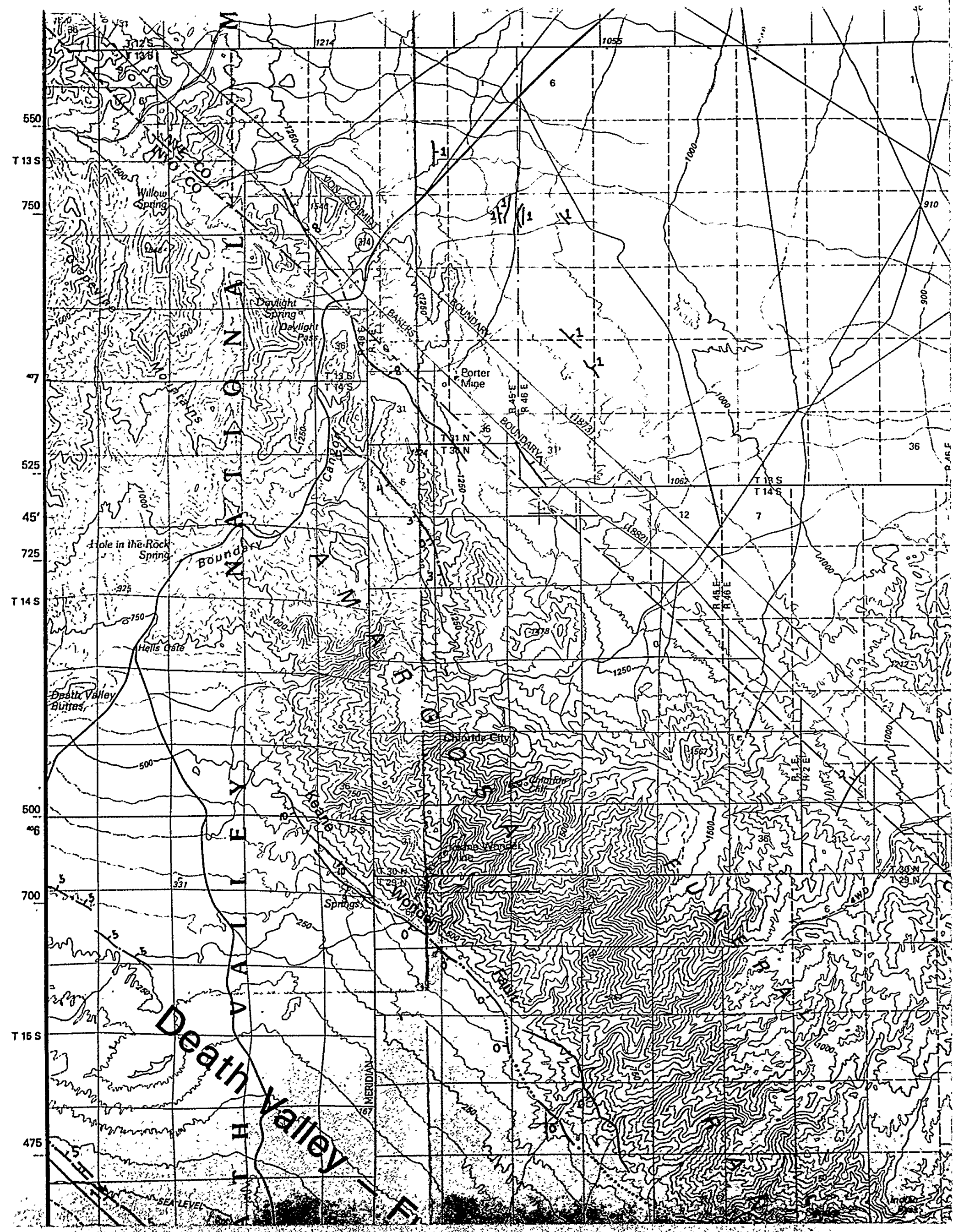




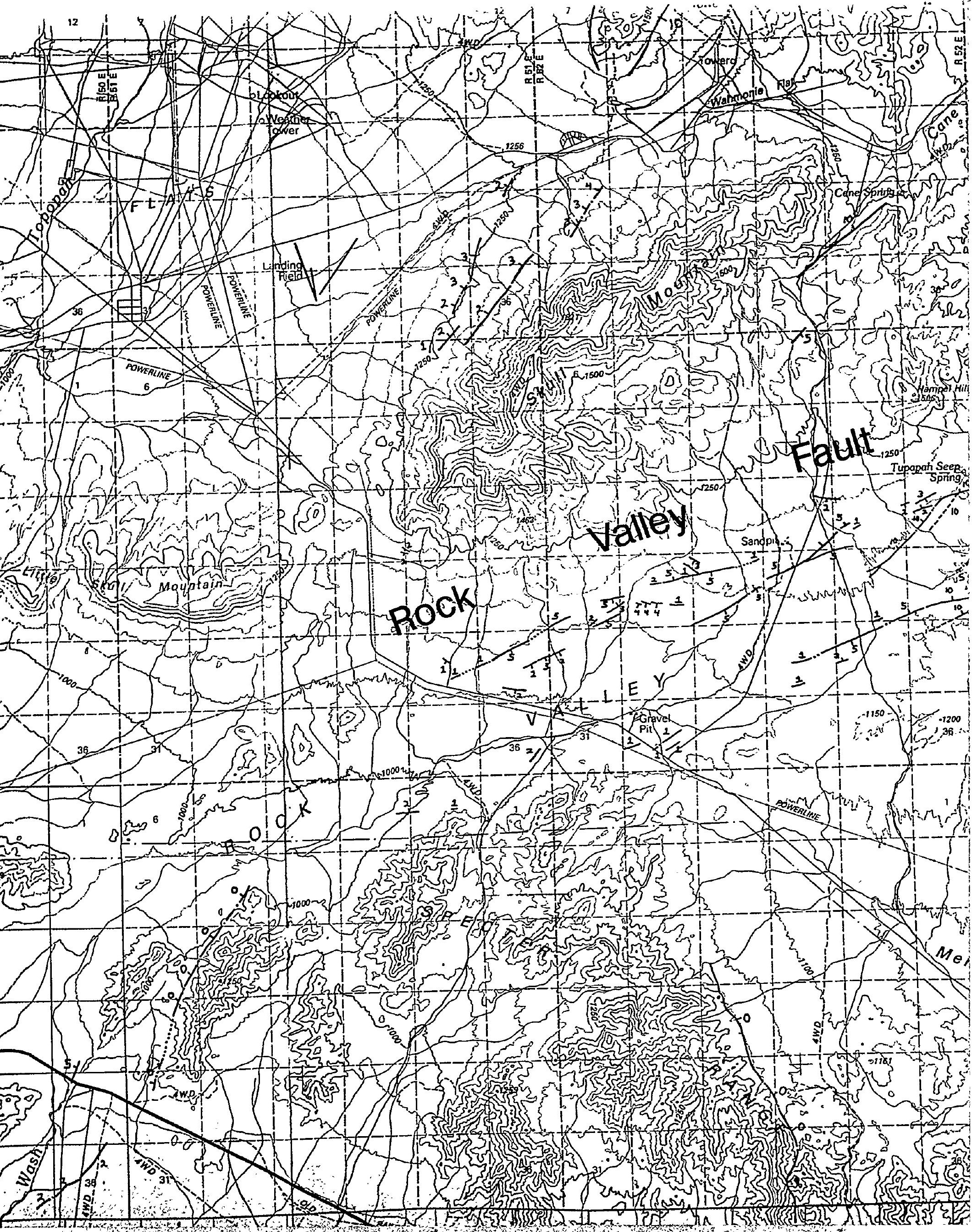




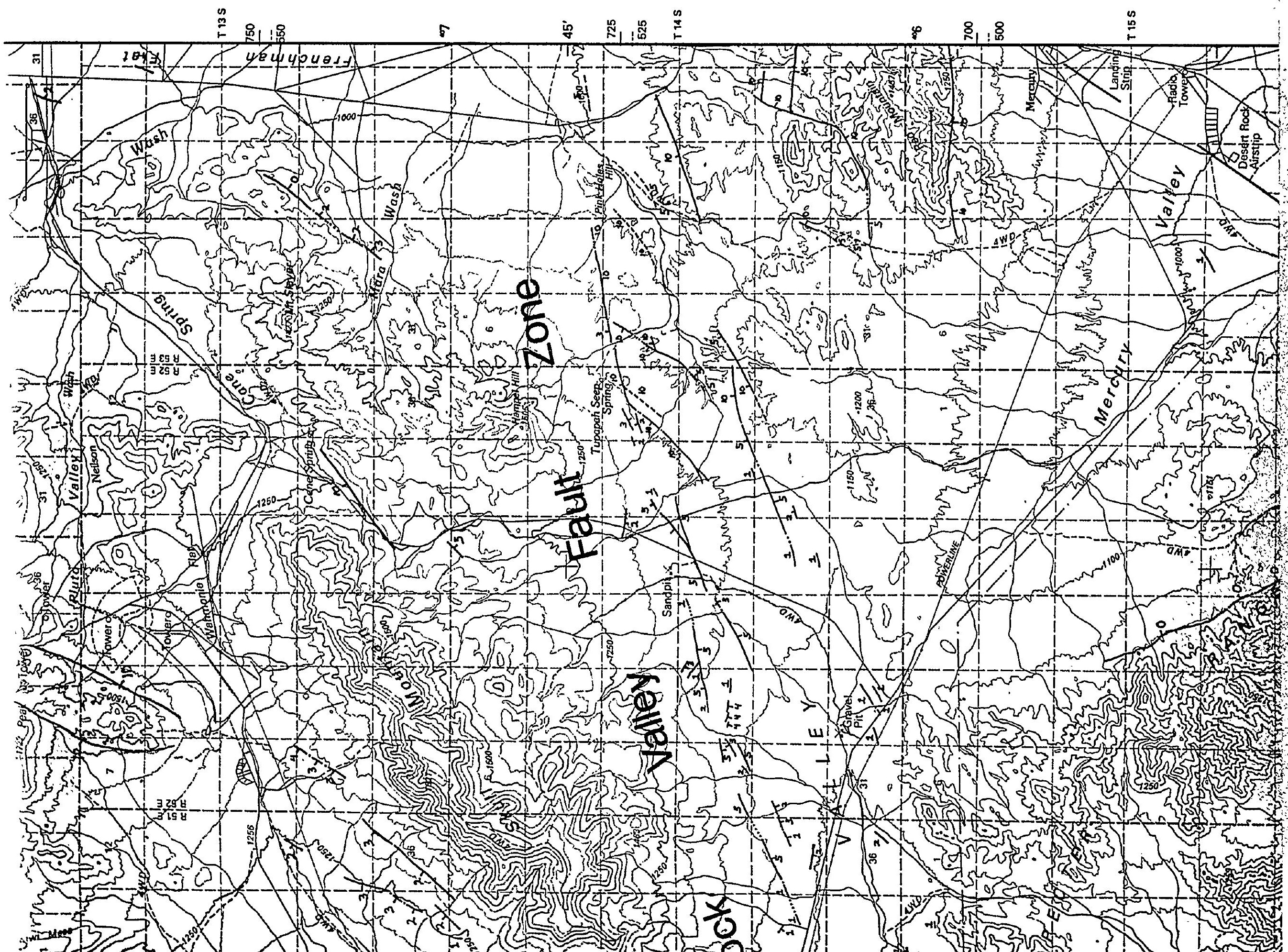




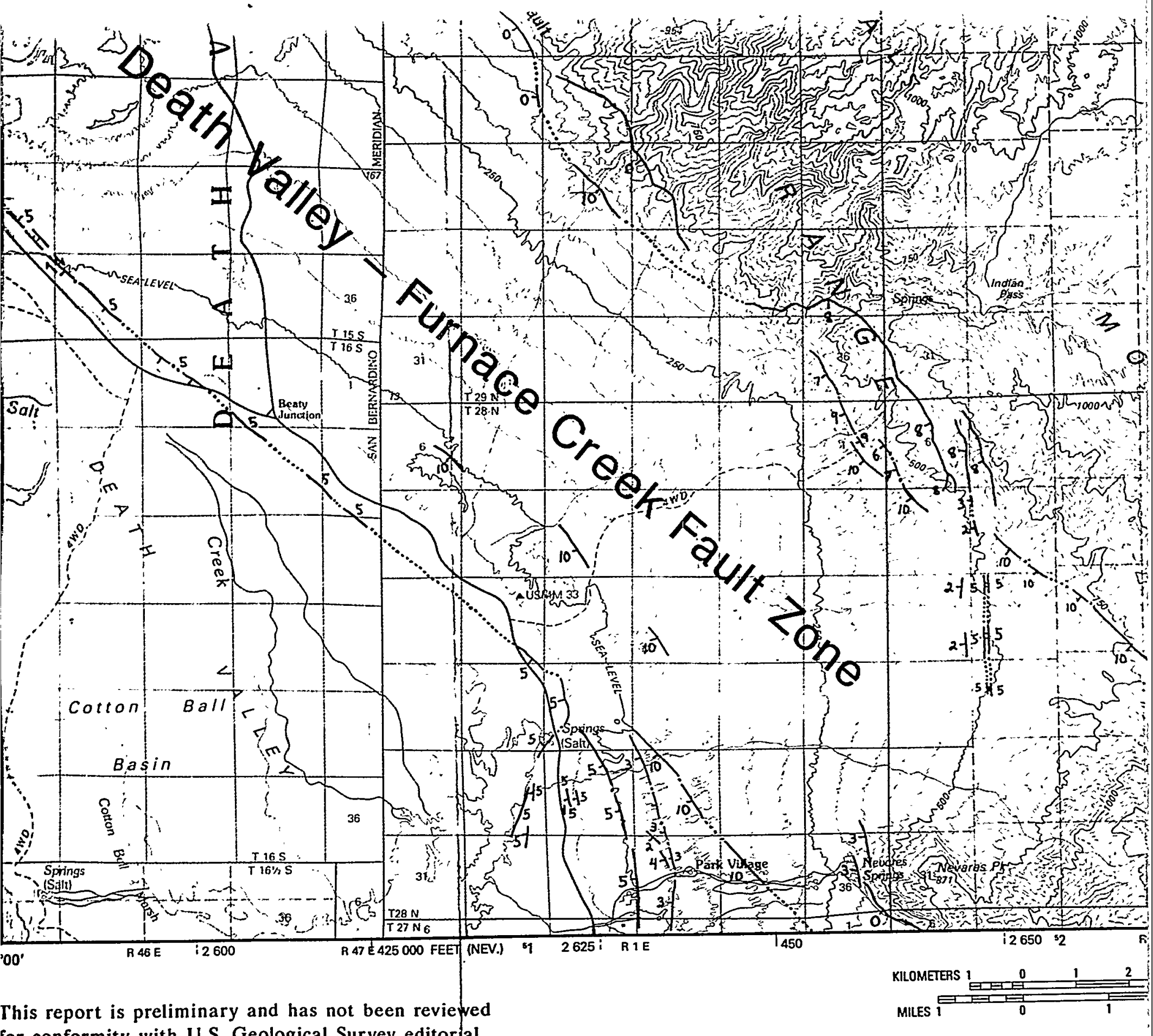
for conformity with U.S. Geological Survey editorial standards or stratigraphic nomenclature 


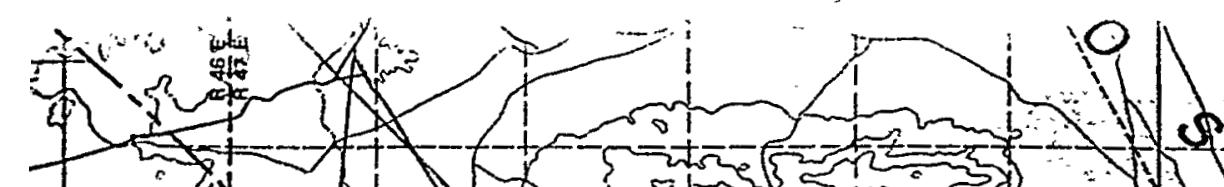

0 matid

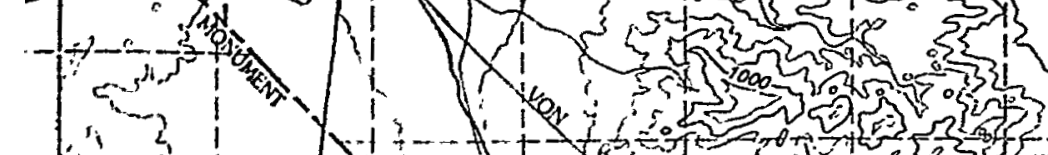

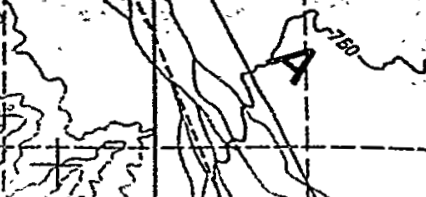
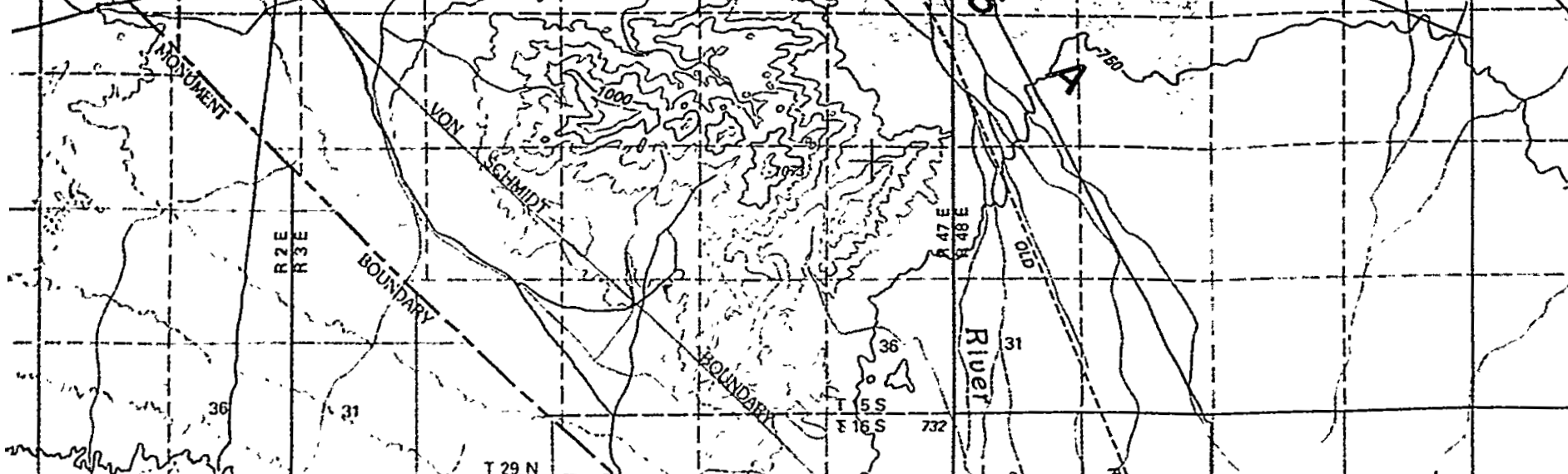

$+1$
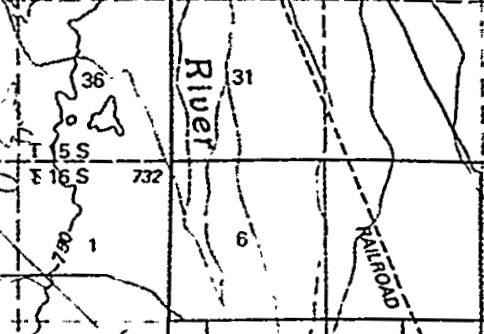

:

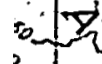

vis

ind

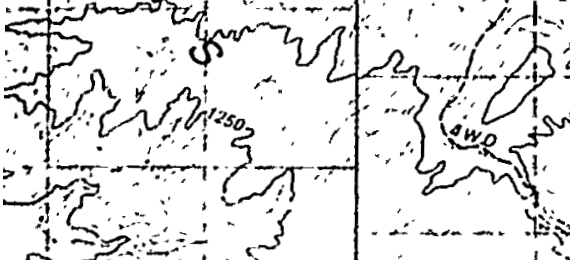

(1)

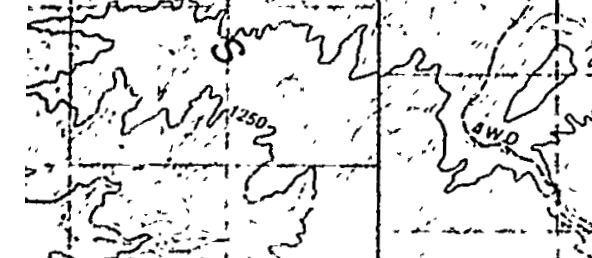

$53,-25$

-6

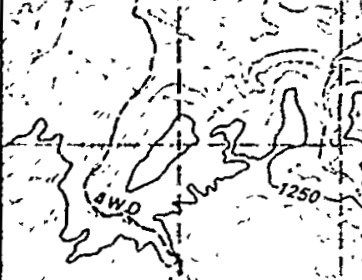

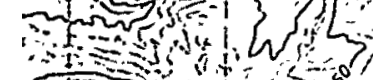

\{10

No

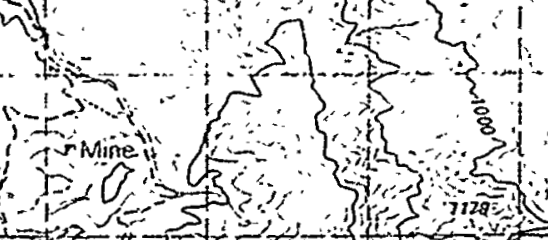

ㄴ..ㄴ.

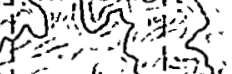
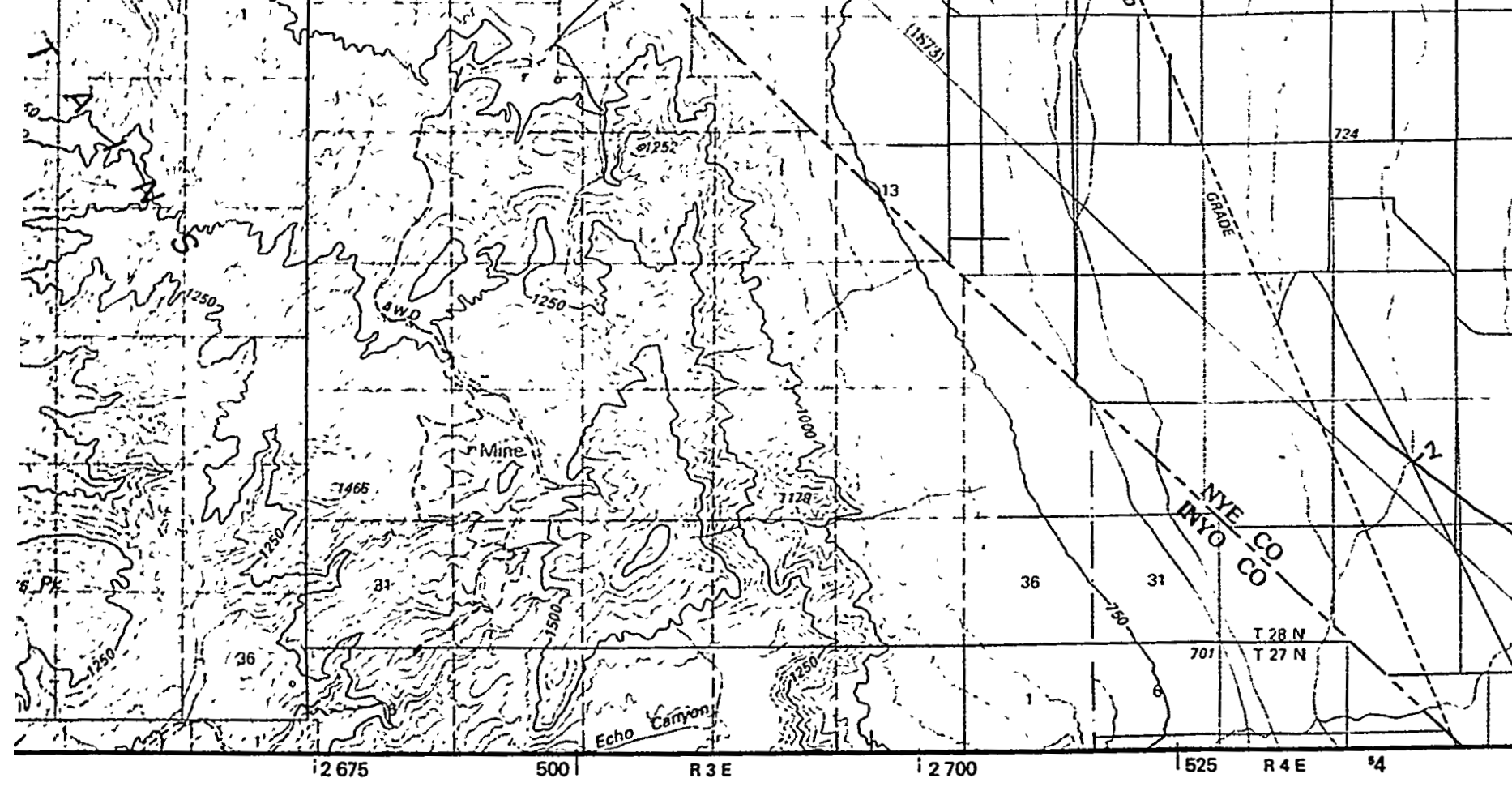

$i_{w}$

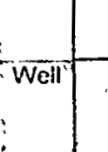

36

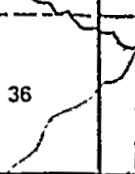




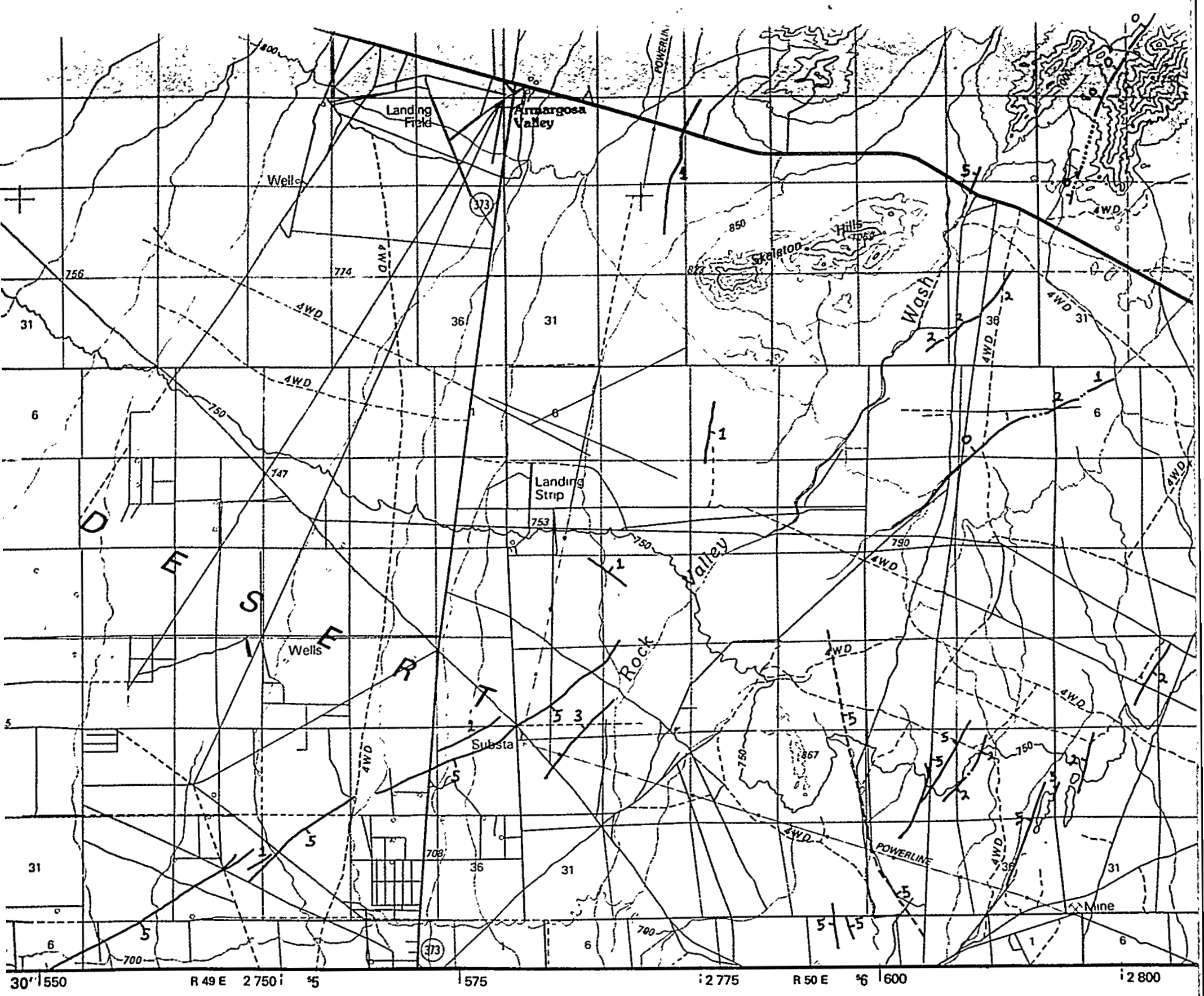

1:100 000 SENTS I KILOMETER ON THE GROUND SRVAL 50 METERS

osits in the Beatty $1: 100,000$ Quadrangle, Nevada उy 


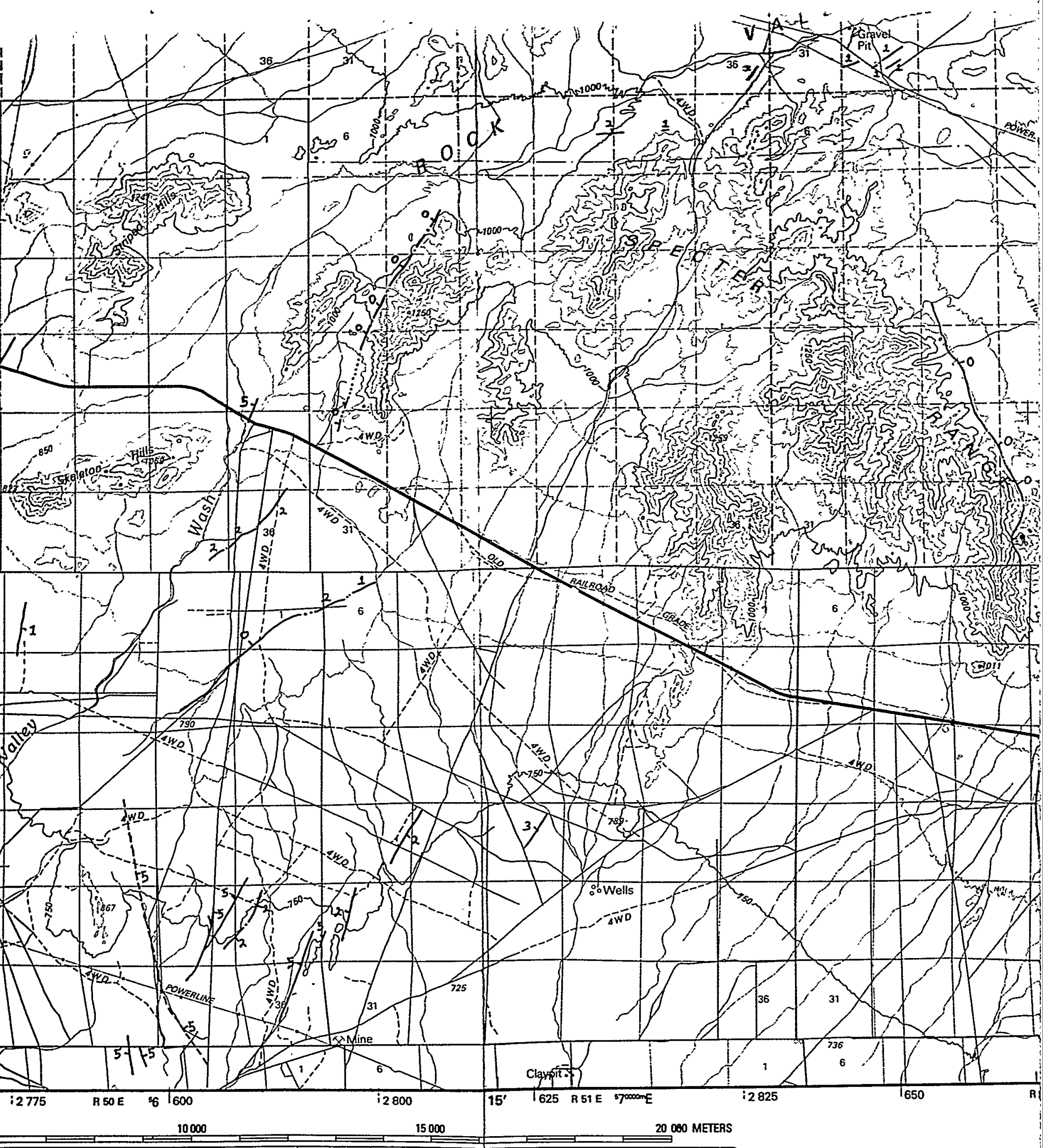




\section{Department of the Interior U.S. Geological Survey}

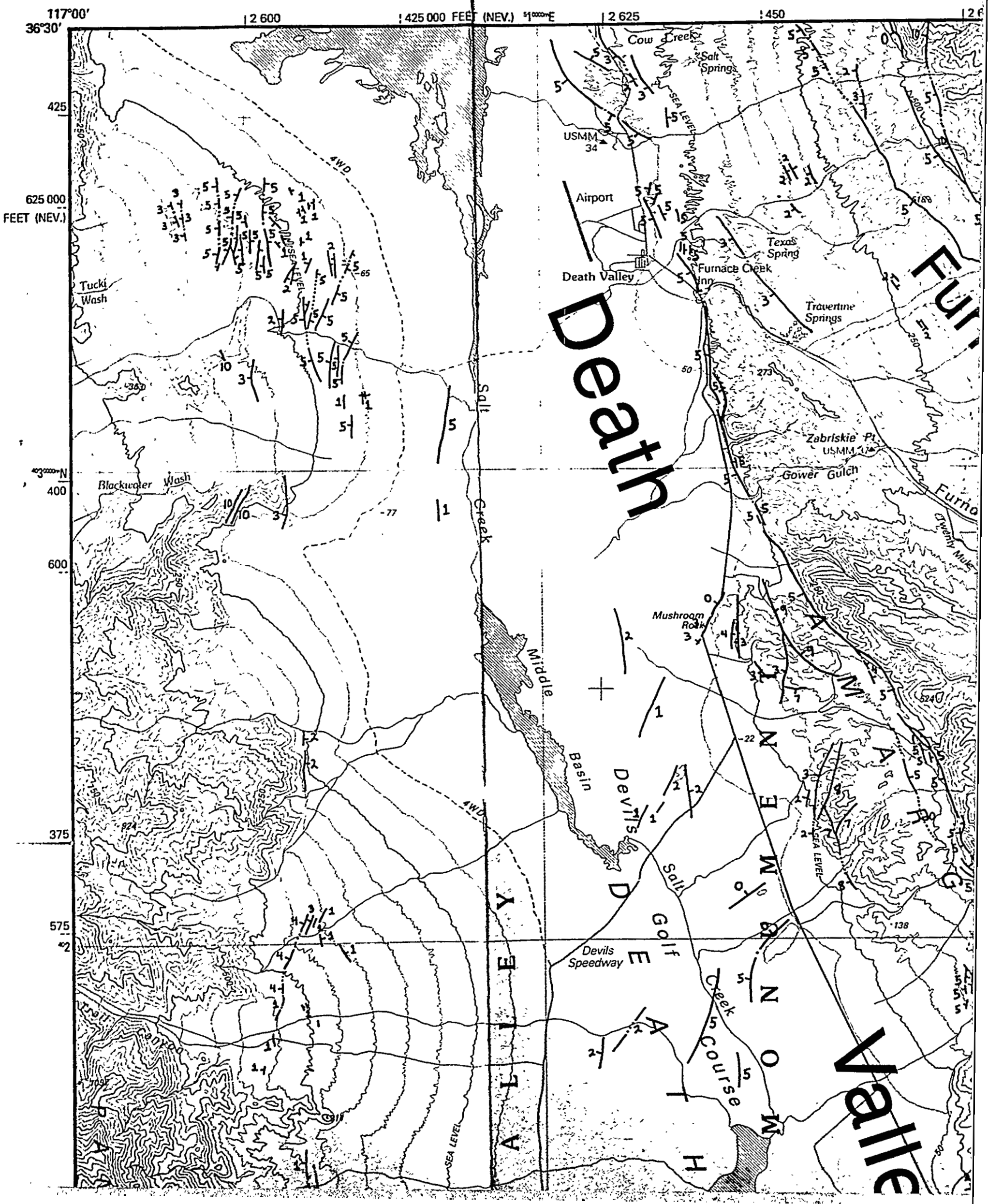




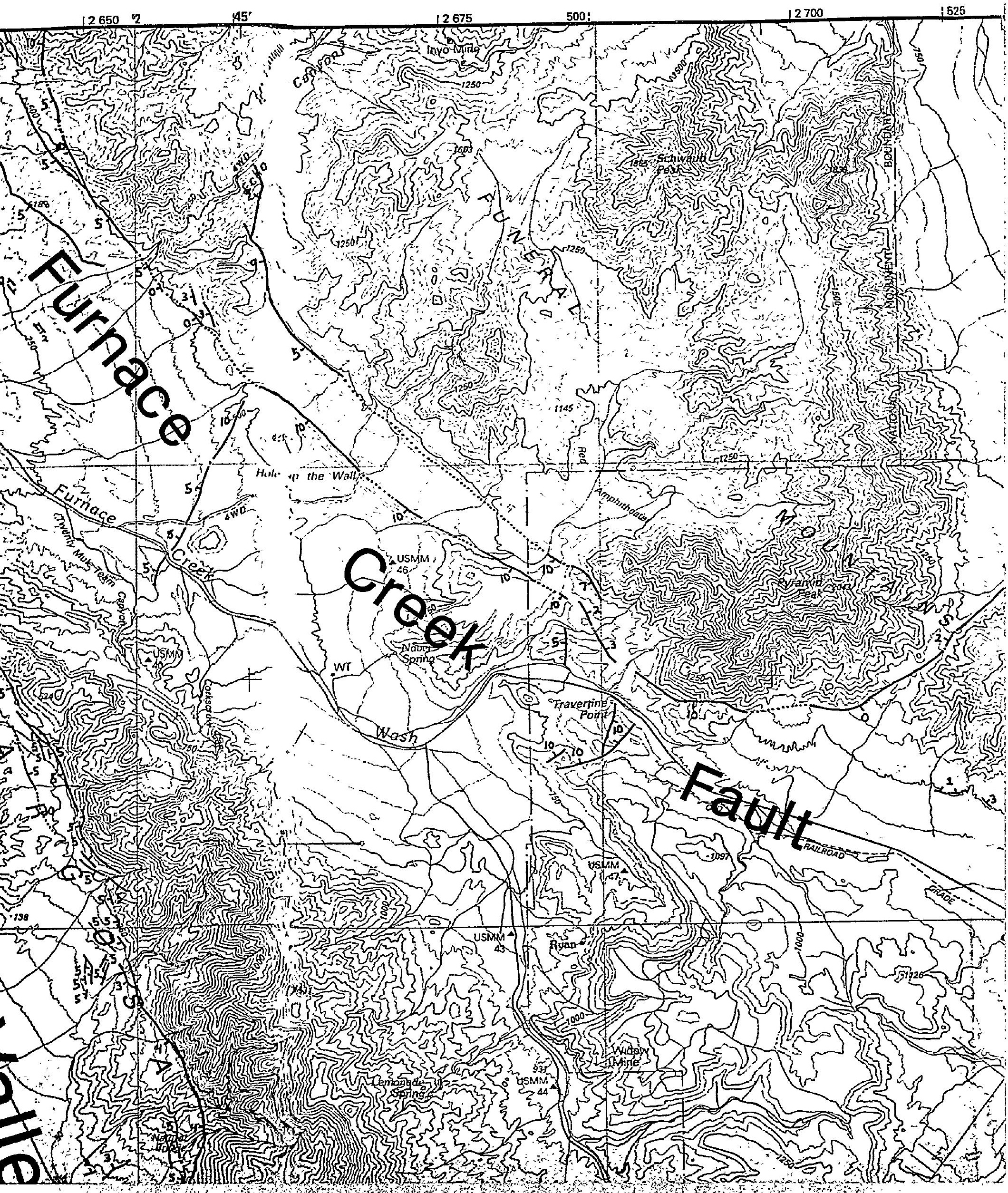




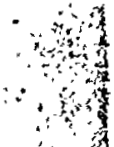 \\ Prepared in cooperation with U.S. Department of Energy}

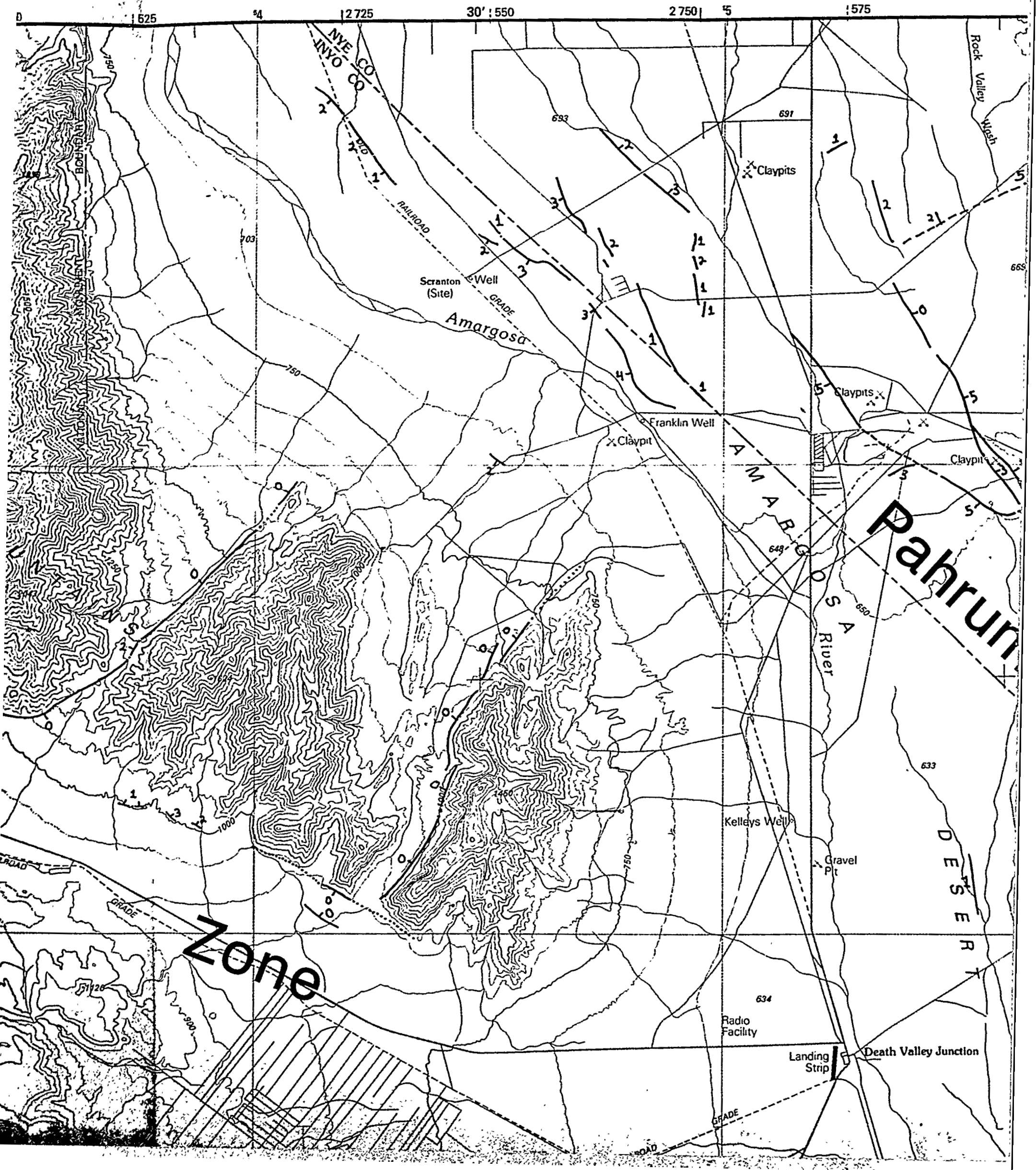




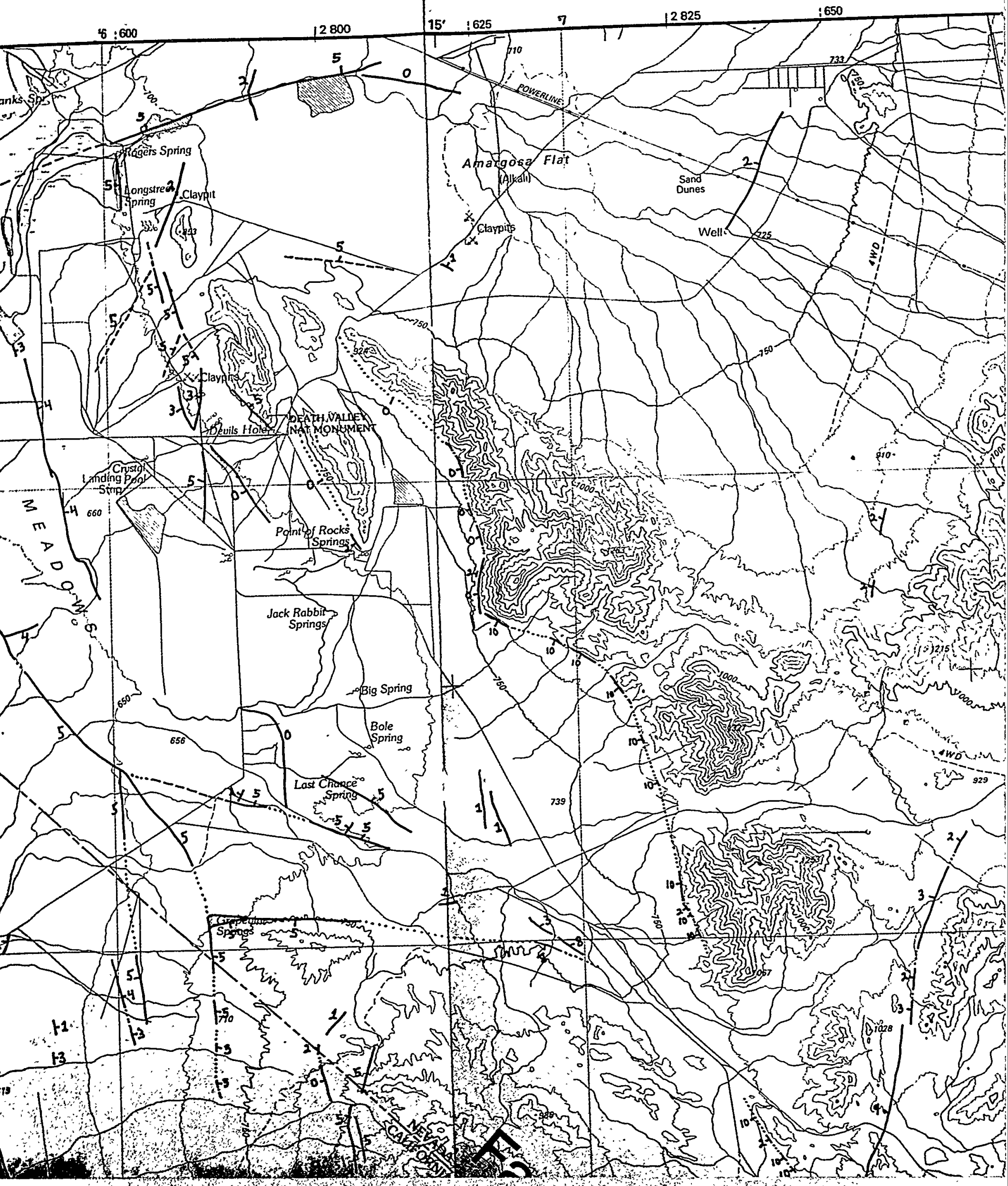




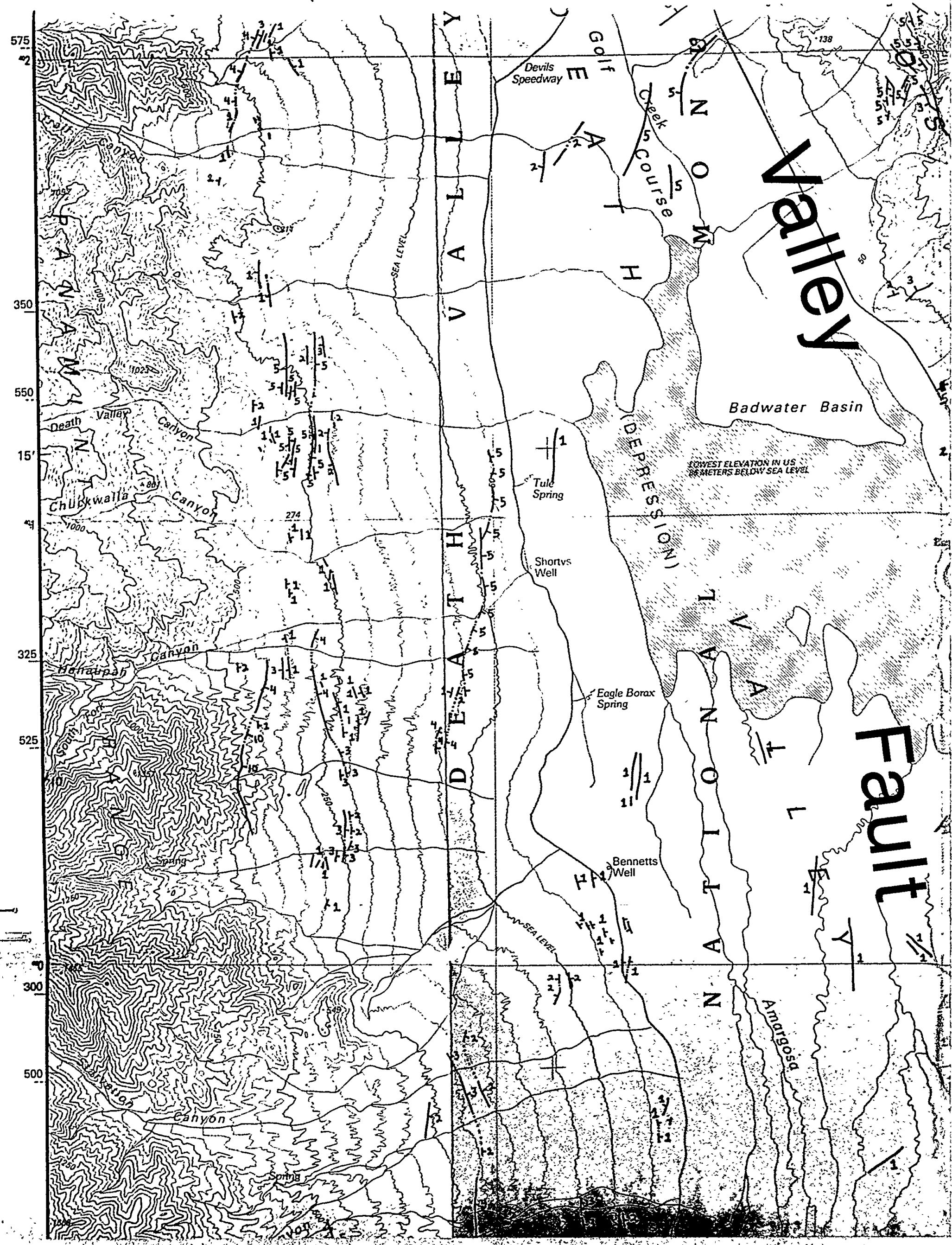


(is s. s. 政

(in

$x_{2}$
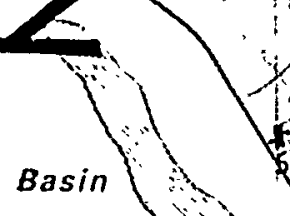

3 .
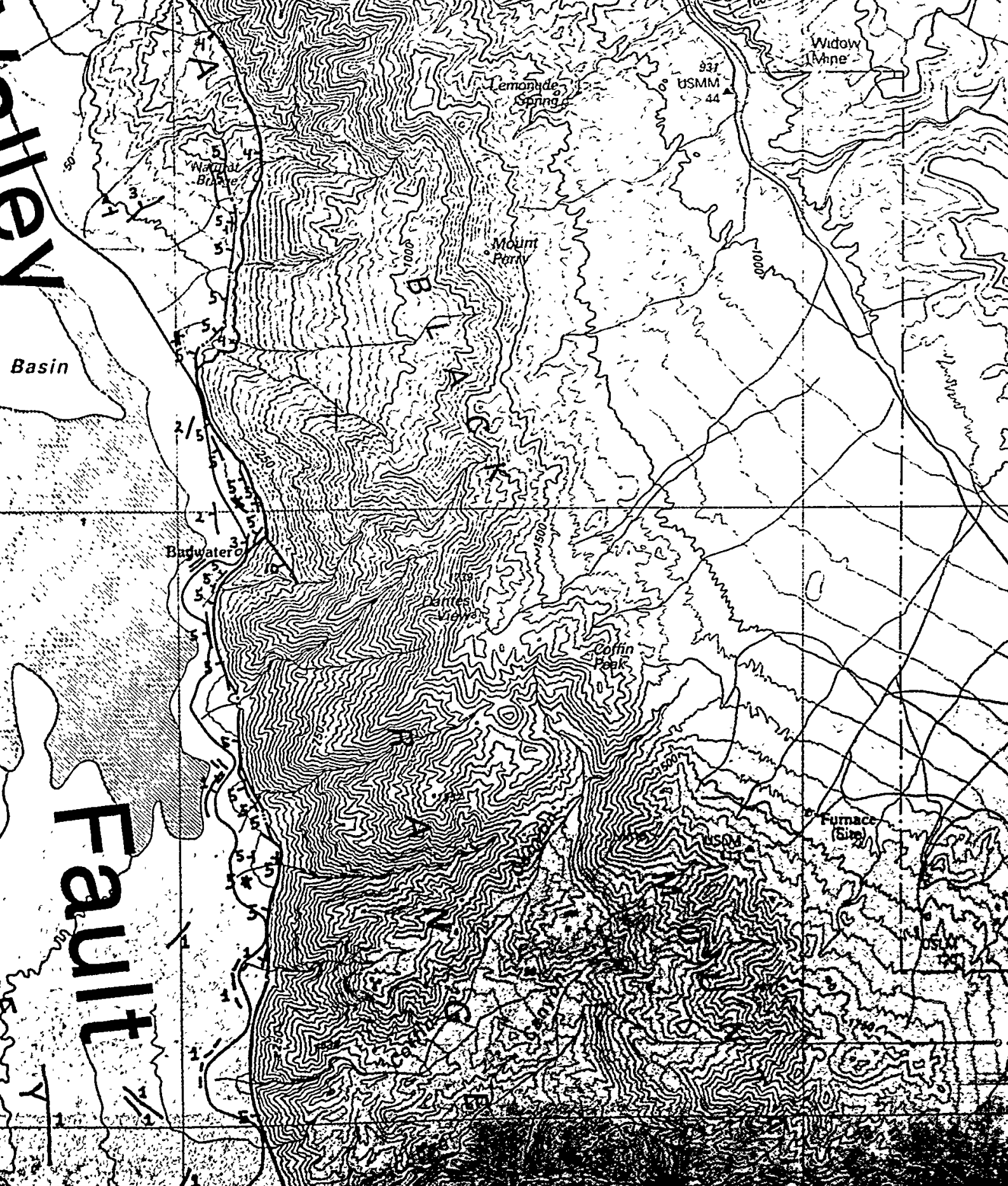

penty

Len

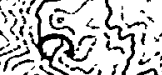

(5) (1)

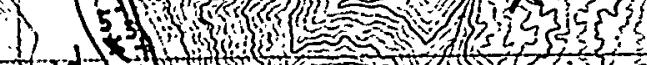
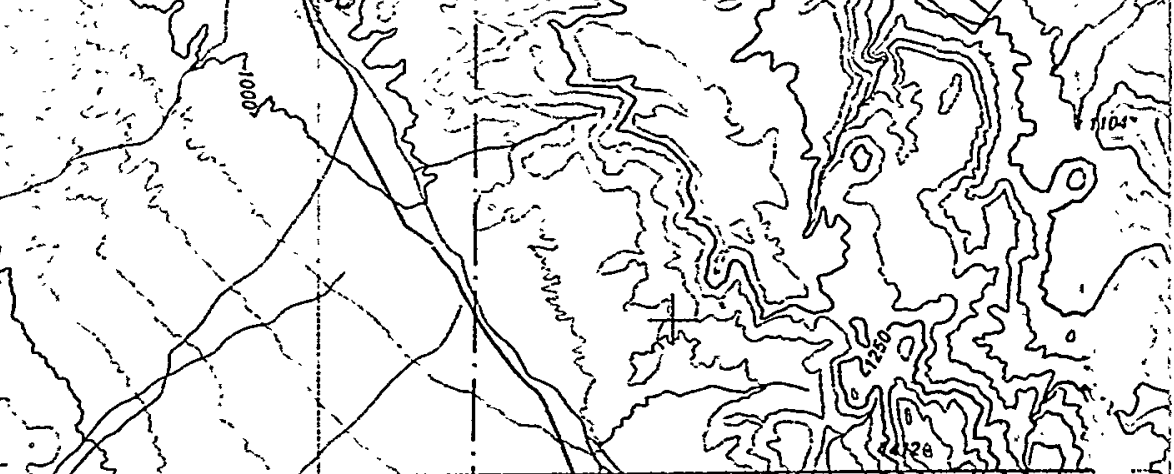

(4)

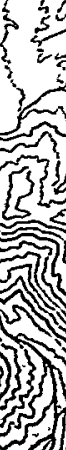

1.

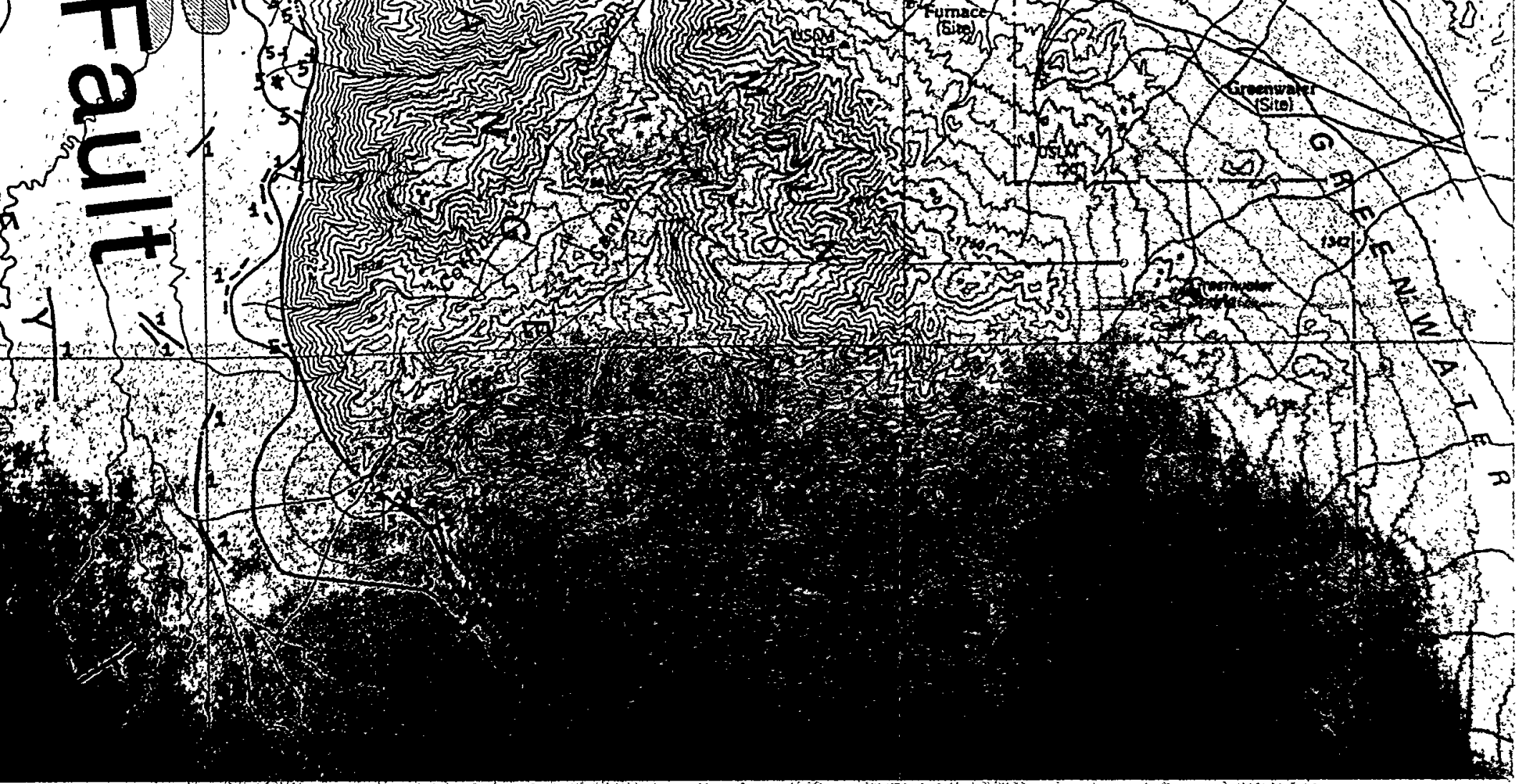

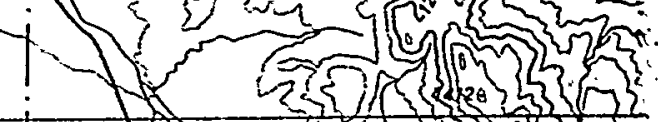

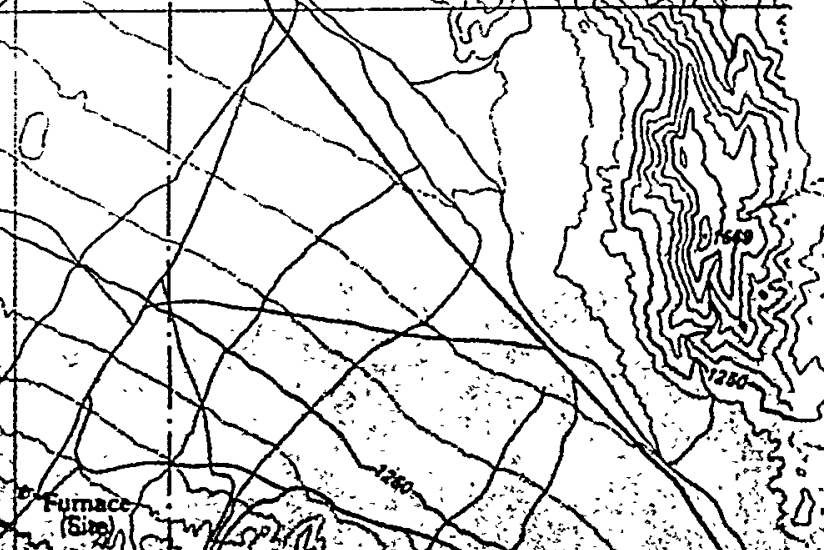




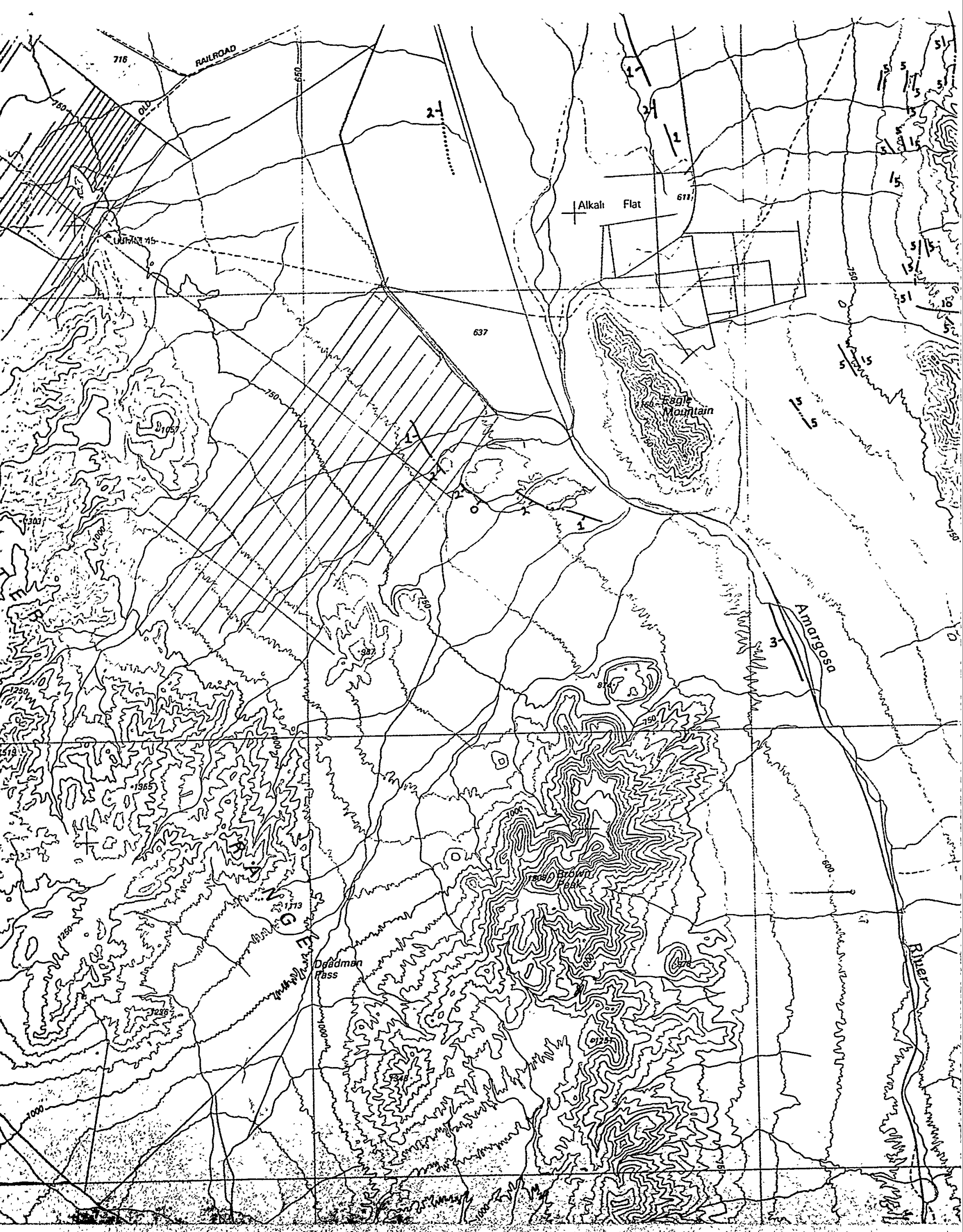




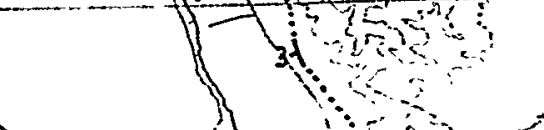

4 a

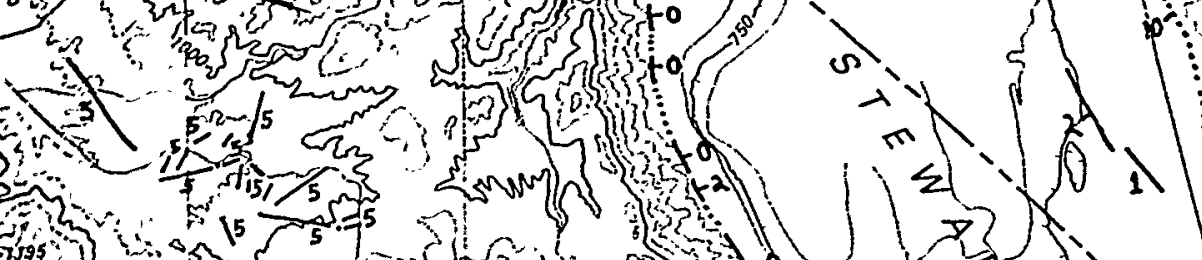




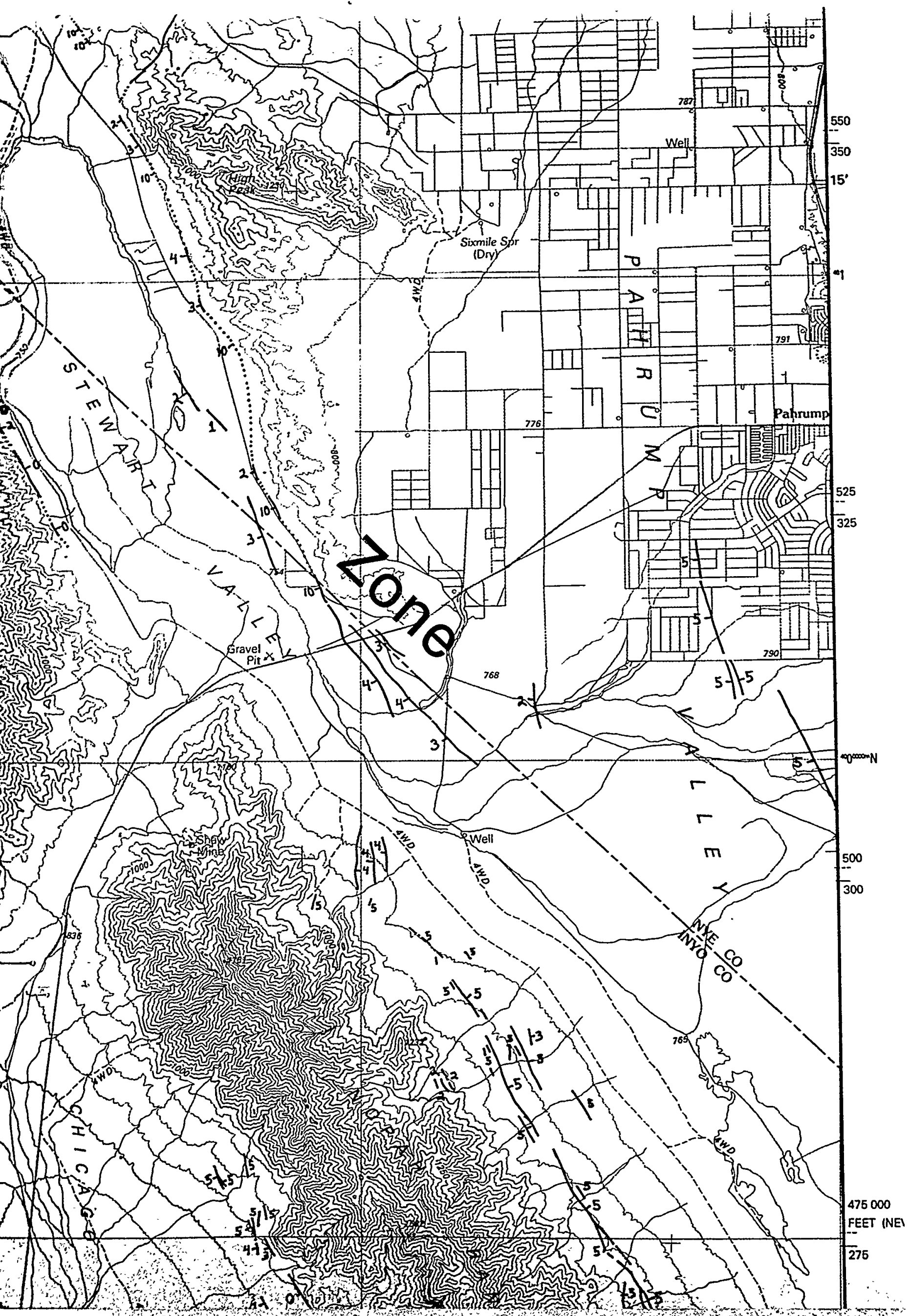


(1)

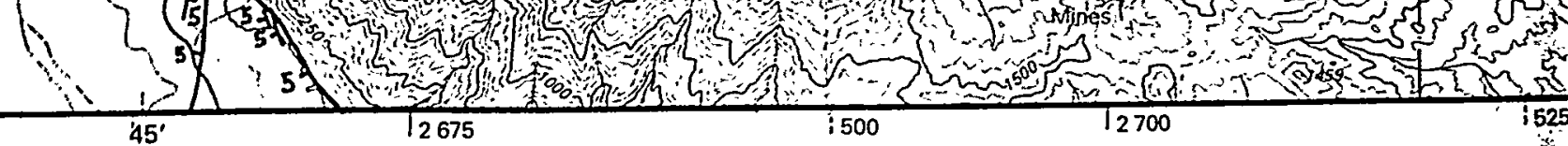

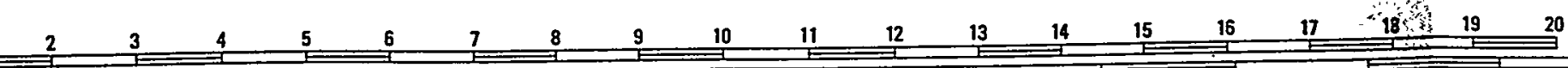

$\frac{2}{5}$

$\frac{11}{7}$

$=\frac{12}{8}$

110




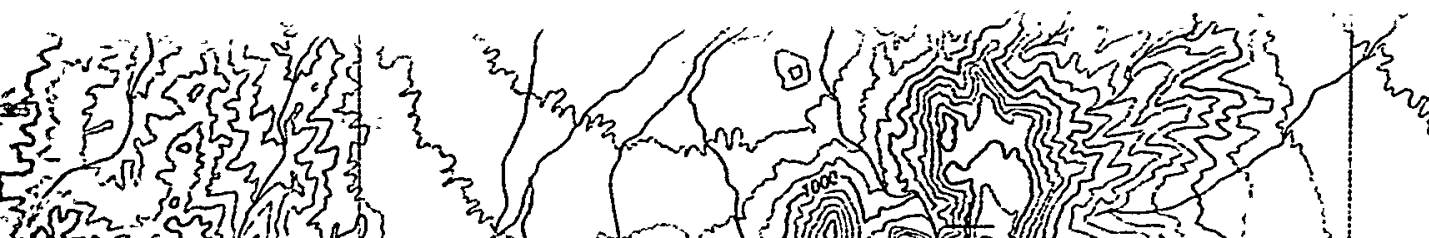
c. $=5,8$

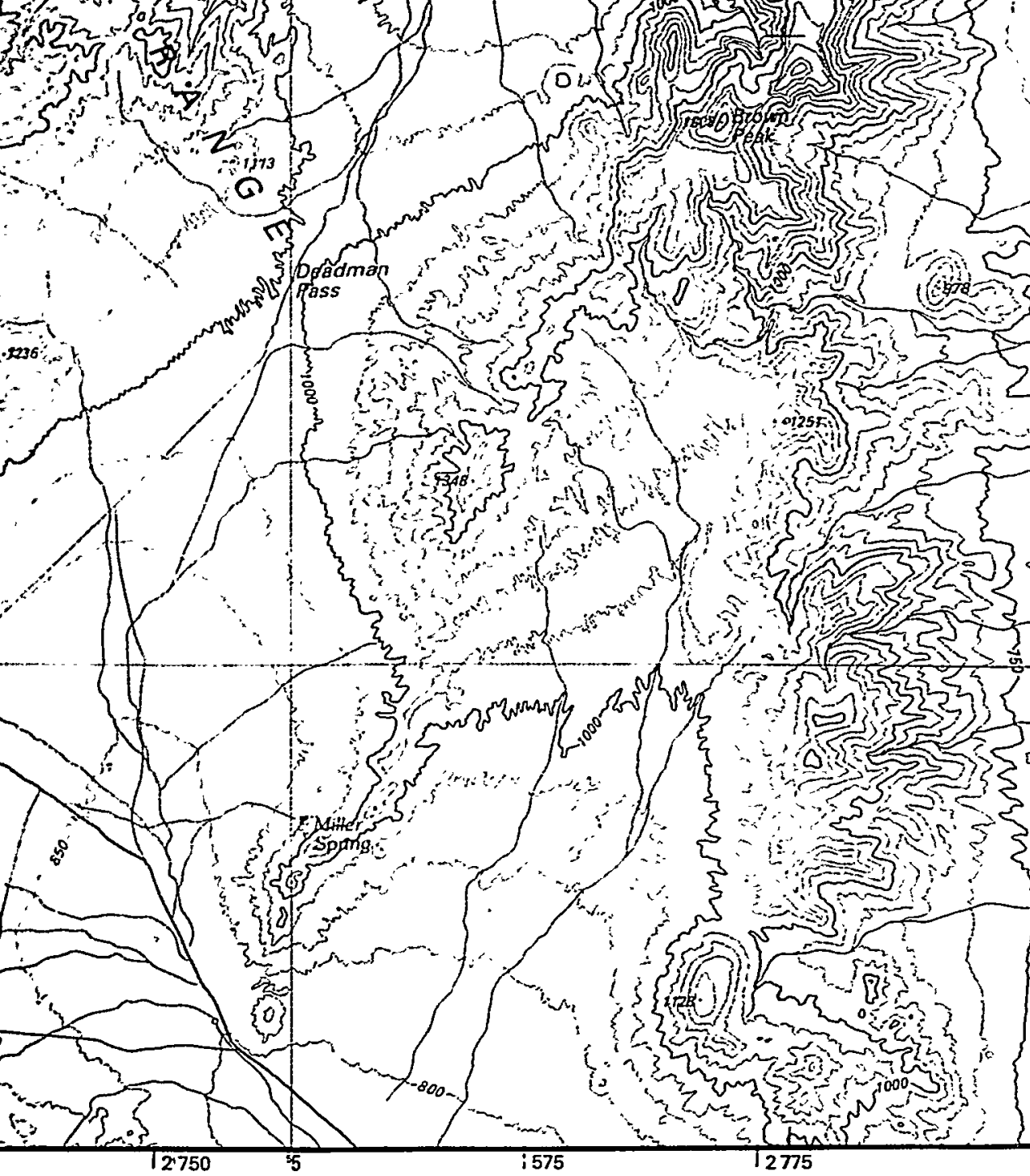




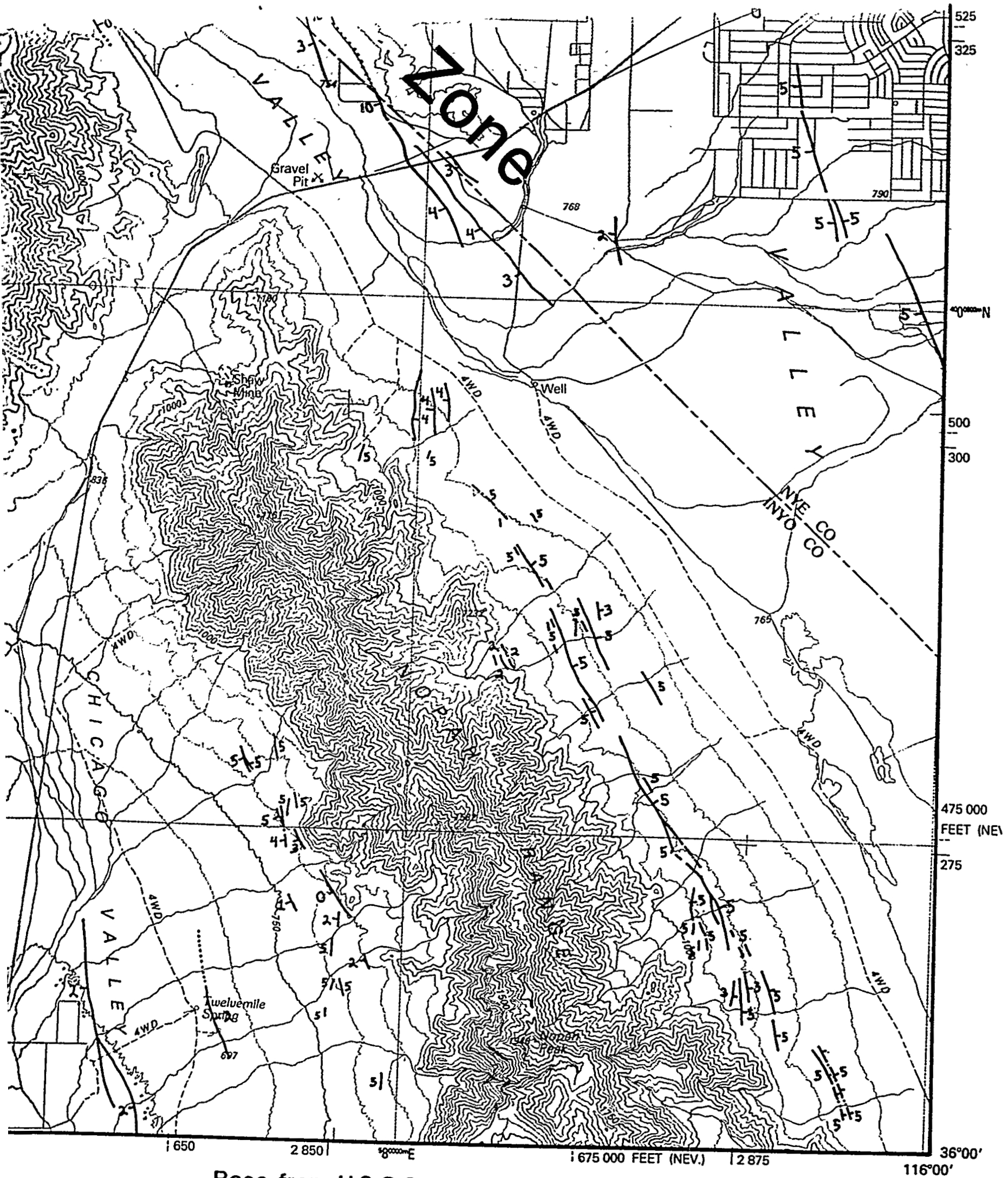

